\title{
Intimate Partner Violence: The influence of job opportunities for men and women
}

\author{
Sonia Bhalotra ${ }^{1}$, Uma Kambhampati ${ }^{2}$, Samantha Rawlings ${ }^{3}$, Zahra Siddique ${ }^{4}$ \\ Forthcoming in World Bank Economic Review ${ }^{5}$
}

\begin{abstract}
This study examines the association of unemployment variation with intimate partner violence using representative data from thirty one developing countries, through 2005 to 2016. It finds that a 1 percent increase in the male unemployment rate is associated with an increase in the incidence of physical violence against women by 0.50 percentage points, or 2.75 percent. This is consistent with financial and psychological stress generated by unemployment. Female unemployment rates have the opposite effect, a 1 percent decrease being associated with an increase in the probability of victimization of 0.52 percentage points, or 2.87 percent. That an improvement in women's employment opportunities is associated with increased violence is consistent with male backlash. The study finds that this pattern of behaviours emerges entirely from countries in which women have more limited access to divorce than men.
\end{abstract}

JEL classification codes: D19, J11, J12

Keywords: Intimate partner violence, domestic violence, abuse, recession, married women's labour force participation, women's empowerment, male backlash.

\footnotetext{
${ }^{1}$ Department of Economics and ISER, University of Essex, Wivenhoe Park, Colchester CO4 3SQ, UK

${ }^{2}$ Department of Economics, University of Reading, PO Box 219 Whiteknights, Reading, RG6 6AA, UK

${ }^{3}$ Corresponding author: Department of Economics, University of Reading, PO Box 219 Whiteknights, Reading, RG6 6AA, UK. Email: s.b.rawlings@,reading.ac.uk Phone: +44 (0) 1183788231

${ }^{4}$ Department of Economics, University of Bristol, The Priory Road Complex, Priory Road, Bristol, BS8 1TU, UK

The authors are grateful to the Editor, Eric Edmonds, for his helpful comments on the paper.
}

${ }^{5}$ doi: $10.1093 /$ wber/lhz030 


\section{Introduction}

Intimate partner violence (IPV) is pervasive, with about one in three women in richer as well as poorer countries reporting abuse over their lifetime (Devries et. al. 2013). It is increasingly being recognized as an important part of the development agenda (WHO 2014, Michau et al. 2015, UN Women 2015a). While there were no targets for violence against women in the Millennium Development Goals, the new Sustainable Development Goals explicitly call for the "elimination of all forms of violence against women and girls" (UN, 2015). IPV tends to be higher in low income countries, being $65.64 \%$ in Central Sub-Saharan Africa and $41.73 \%$ in South Asia, compared to 27.85\% and 21.32\% in Central Europe and North America, respectively (Devries et. al. 2013). It not only harms the physical and mental health of women, it also harms children (Ellsberg et al. 2008, Aizer, 2011, Rawlings and Siddique, 2018). In the last decade, many countries have implemented laws criminalizing IPV, but the extent to which such laws are upheld varies hugely (OECD Development Centre, 2014).

This paper considers how IPV varies with macroeconomic conditions, in particular, male and female unemployment rates, using comparable data for thirty one developing countries. It considers male and female unemployment shocks, each conditional upon the other. Since these are correlated with one another but may have different impacts on violence, omitting either one will tend to bias the coefficient on the other and this study shows that this is the case. ${ }^{6}$ Of particular interest is how violence against individual women is associated with improved aggregate employment prospects for women. This is important because many interventions in developing countries, for example, microcredit schemes and skills training programmes, are designed to increase women's employment. The direction

\footnotetext{
${ }^{6}$ Independent variation in male relative to female unemployment rates may arise for instance because recessions have larger impacts on sectors of the economy that are more intensive in male-labour (Anderberg et al. 2016) or on account of added worker effects that lead to more women seeking work during recessions (Bhalotra and Umana-Aponte 2015 and references therein).
} 
of any association is unclear unless it is assumed that improved outside options can be leveraged to the woman's advantage. On the one hand, increases in women's employment opportunities may be expected to empower them and thus lower violence and, on the other, this may challenge gender norms leading to increased violence.

This study finds that a 1 percent increase in the male unemployment rate is associated with an increase in the incidence of physical violence against women by 0.50 percentage points (or 2.75 percent) while a one percent increase in female unemployment rates is associated with a reduction in the incidence of violence by 0.52 percentage points (or 2.87 percent). The pooled (male plus female) unemployment rate has no significant association with $\mathrm{IPV}^{7}$. The results are robust to a number of checks, including different measures of business cycle variation, and a leave-one-out analysis. Although the study avoids using this as the main specification, if the unemployment rate is replaced with the individual (un)employment status of the woman, a similar result is found, namely, that the employment of the individual woman is predictive of IPV. The study investigates whether these associations vary with whether there are restrictions on women's access to divorce and find that the results emerge entirely from countries in which women face greater legal and social barriers to divorce than men. ${ }^{8}$ In countries where women and men have equal access to divorce, the results are reversed, in line with recent results for the UK (Anderberg et al. 2016) and the US (Aizer, 2010).

A contribution of this study is that it paints a broad brush picture for a large sample of developing countries. A further contribution is that it examines how the association of violence with male and female unemployment rates varies with the cultural and legal accessibility of divorce for women relative to men. The study shows a striking reversal of results by whether or not access is equal. However, it is not possible to obtain causal identification of the relationships of interest in this

\footnotetext{
${ }^{7}$ This result is also shown in Anderberg et al (2016).

${ }^{8}$ The authors are grateful to the Editor, Eric Edmonds for making this interesting suggestion.
} 
large and diverse sample. ${ }^{9}$ Earlier studies have tended to focus on the experience of individual countries, and often on responses of IPV to an individual woman working,(e.g. Bowlus and Seitz, 2006; Chin, 2012; Tertilt and Van den Berg, 2015) and these studies are mostly set in developed countries. ${ }^{10}$ In contrast, this study considers macroeconomic shocks in a cross-section of countries over time. ${ }^{11,12}$

Closely related to our approach are two recent studies, set in the US and the UK respectively, which consider how macroeconomic changes in relative male and female economic opportunities influence IPV. ${ }^{13}$ Using demand driven variation in female relative to male wages at the county level in the United States, Aizer (2010) shows that IPV is decreasing in women's relative wages. Anderberg et al. (2016) similarly find that improvements in the relative employment rates of women in the UK are associated with lower rates of IPV, and that male unemployment acts to inhibit IPV. ${ }^{14}$ These findings can be rationalized with reference to a household bargaining model in which better labour market prospects for women relative to men increase their bargaining power by improving their outside options. The higher the threat point of women, the more averse men are to committing violence that may enhance the risk of marital dissolution (Farmer and Tiefenthaler, 1997). This study is able to

\footnotetext{
${ }^{9}$ As discussed below, recent country specific studies instrument unemployment rates with a Bartik-style instrument. This is not possible in the sample in this paper since it would be necessary to gather data on industrial composition for every country in the sample. On the other hand, by virtue of using data from several countries, the results have wider scope. The study is also able to investigate the role of barriers to divorce.

${ }^{10}$ Understanding domestic violence in developing countries is important because rates are higher and women's outside options are more limited, related to their having weaker property rights (Agarwal, 1994; World Bank, 2012), more limited labour market opportunities, and facing cultural and legal barriers to divorce.

${ }^{11}$ This is useful because the macroeconomic unemployment rate captures changes in all women's employment opportunities, including those who do not work.

${ }^{12}$ Here, the study has summarized research predicting IPV, without attempting a comprehensive survey and focusing upon studies that model IPV as a function of individual employment or aggregate unemployment rates. There is a wider literature. For instance, Gulesci et al. (forthcoming) find that mothers whose daughters were exposed to compulsory schooling increases are 12 percentage points less likely to find domestic violence justifiable, and there is not similar spillover associated with increases in their son's education. Other studies have explained familial or regional variation in IPV with reference to cross-sectional differences in childhood experiences or the historical shaping of gender norms respectively (Alesina et al. 2016; Tur Prats 2015).

${ }_{13}^{13}$ Both of these studies use the Bartik instrument, relying upon variation in local industry shares.

${ }^{14}$ Other studies that highlight the beneficial impacts of women's own employment and income for IPV include Bowlus and Seitz (2006), Tauchen et al. (1991), Farmer and Tiefenthaler (1997) and Pronyk et al. (2006).
} 
replicate this pattern of results in this sample but only for the small fraction of countries in which women and men are similarly placed to access divorce (as is the case in the UK and US).

The main findings contrast sharply with the results for the UK and the US and can be explained by women in many low and middle income countries having weak outside options on account of social norms and embedded economic and political disadvantage (Bloch and Rao 2002, Anderson and Eswaran, 2009). For many of the countries in the sample, woman lack equal access to divorce relative to men (Table S1.2 in the supplementary online appendix, available with this article at The World Bank Economic Review website). This limits the extent to which divorce can act as a margin of adjustment and leaves women within marriage in a more vulnerable position even when economic opportunities for them improve.

As a result, improved job opportunities for women may not increase the probability that they exit marriage. Instead, outside job opportunities for women may act to threaten gender stereotypes and prime male identity, leading to male backlash (Macmillan and Gartner, 1999). Some previous studies have documented evidence of backlash whereby men react negatively to higher earnings of women or to women performing non-traditional roles (Schuler et al 1996, Luke and Munshi 2011, Mani 2011, Gagliarducci and Paserman 2012, Bertrand et al 2015, Gangadharan et al 2016). The coefficient on the male unemployment rate flips in developing countries for a similar reason. If divorce initiated by the woman is not a real threat, then male unemployment rates will not tame men but, instead create psychological and financial stress that can lead to higher IPV (Angelucci 2008). The psychological stress is possibly greater than in richer countries because of male-breadwinner stereotypes being stronger, and the financial stress is probably greater because the family relies primarily on male income and there is limited state income support. Male unemployment may also 
raise IPV by reducing the opportunity cost of men's time (Blattman and Miguel 2010) ${ }^{15}$, and increasing exposure of the woman to the man if he spends more time at home (Chin, 2002). ${ }^{16}$

Similarly to this paper, but using Spanish data, Alonso-Borrego and Carrasco (2017) and TurPrats (2017) find that improved female employment opportunities increase violence against women for some (although not all) women. ${ }^{17}$ Alonso-Borrego and Carrasco (2017) find that female employment reduces violence only if the female's partner is employed as well. Tur-Prats (2017) finds that in Spanish territories with a historical nuclear family tradition a decrease in female unemployment relative to male unemployment increases IPV due to cultural norms pertaining to gender. ${ }^{18}$ This study shows the critical role of women's access to divorce in explaining this relationship across a number of developing countries covering a wide geographical area. It may be that access to divorce is itself influenced by historical cultural norms pertaining to gender. However given the wide geographical scope of our study it is not possible to use consistent controls for such historical cultural norms, so the study cannot tease out the separate influence of gendered norms vs access to divorce in this study.

Section 2 describes the data and Section 3 the methodology. Section 4 provides the estimation results, Section 5 the robustness checks, and Section 6 provides a discussion and conclusions.

\section{Data}

\footnotetext{
${ }^{15}$ The literature on civil conflict emphasizes the opportunity cost of time as a causal factor. It argues that economic shocks that leave men without jobs leave them vulnerable to being drawn into soldiering (Blattman and Miguel 2010).

${ }^{16}$ The idea that exposure or inadvertent increases in time that the partners spend together increases IPV is analogous to the idea in the wider crime literature that incarceration reduces crime.

${ }^{17}$ There is no similar evidence previous to this study for developing countries.

${ }^{18}$ Specifically, she finds that, in areas in which deep-rooted social norms support the male breadwinner stereotype, decreases in female relative to male unemployment increase violence. In contrast, in areas in which cultural norms viewed both men and women as providers, she finds evidence consistent with the existing US and UK evidence, with increases in female unemployment raising IPV.
} 
The study uses individual data from the Demographic and Health Surveys (DHS) which are large scale, repeated cross-sectional household surveys that use standardised questionnaires which are comparable across countries.

\section{Intimate partner violence}

Since 1998 the DHS has included a standardised domestic violence module which asks women if they have ever experienced specific acts of physical, emotional and sexual abuse. Since 2005, the DHS also asks women if they experienced any of these three forms of violence in the twelve months preceding the survey date. The study analyses reports of abuse in the last twelve months so as to exploit the timing of unemployment shocks. A potential concern with self-reported measures of IPV is that women may systematically underreport its incidence (Kishor, 2004). The DHS surveys attempt to minimize this through methods of women selection, interviewer training, and interview technique. Specifically, only one eligible woman per household is selected for the domestic violence module so as to reduce the likelihood that others in the household are aware of the nature of the questions. Women are asked the questions only towards the end of the interview so that a rapport has been built up between interviewer and respondent before the questions are posed, questions on IPV are only asked if absolute privacy is ensured, and translators are avoided to ensure privacy. Finally, interviewers are provided with extensive training regarding the appropriate way to ask questions of such a sensitive nature. $^{19}$

Another possible concern is that reporting behavior changes endogenously with male vs female empowerment. It seems plausible that secular (permanent) changes in relative unemployment rates will empower or disempower women to report violence. However, it is less plausible that

\footnotetext{
${ }^{19}$ Some recent, limited, evidence from Peru suggests that underreporting may occur for highly educated women (Aguero and Frisancho, 2017), but it is unclear how generalizable this is for other country contexts. In any case, in all cases, this study controls for education in our analysis. The estimates should remain unbiased and consistent with possible measurement error in the dependent variable provided this measurement error is uncorrelated with the explanatory variables
} 
reporting changes in response to transitory deviations from trend. This concern is also mitigated by the fact that reporting in the DHS is not observable by husbands, due to measures taken by the DHS surveyors to ensure privacy and confidentiality, described above. ${ }^{20}$ Anderberg et al. (2016) use data from a crime survey which, in principle, has the same issues as our data. Other studies have used more institutionalized data which have different limitations. For instance, Aizer (2010) uses hospitalization data, but only severe cases of IPV are hospitalized. Mani et al. (2012) use police reports, but many women are reluctant to report IPV to the police for fear that their husbands will either exercise backlash or be arrested and taken away (e.g. Iyenger 2009, Amaral et al. 2018).

The estimation sample includes 31 and 26 countries, respectively, for which physical and sexual violence data from the DHS are available for 2005-2016 (see Table S1.1). ${ }^{21}$ Estimates are reported for each of physical and sexual violence and their sum. The study does not use emotional abuse as it is a more subjective measure of abuse. There is substantial variation in the incidence of physical and sexual violence across countries; see Figures $1(\mathrm{a})$ and $1(\mathrm{~b}){ }^{22}$

\section{Unemployment rate shocks}

Data on male and female unemployment rates are obtained from the World Development Indicators (WDI), sourced from the ILOSTAT database. ${ }^{23}$ Although violence measures are only available for

\footnotetext{
${ }^{20}$ Only $0.94 \%$ of women in the sample were selected for the domestic module but not interviewed due to lack of guaranteed privacy.

${ }^{21}$ The sample size for sexual violence is smaller, because in five countries only one of the questions on sexual abuse is included, so that the measure of sexual violence in these countries is not comparable to the rest of the sample. As a result, these countries are excluded from the sexual violence sample (see Table S1.1).

${ }^{22}$ There is significant coincidence of physical and sexual violence: 19.81 percent of women reported experiencing some form of violence over the last twelve months; of these women, 24.23 percent report both physical and sexual violence. Of the sample of women who reported suffering some form of violence in the last twelve months, 65.81 (9.96) percent reported physical (sexual) violence only.

${ }^{23}$ The ILO estimates are based on either household labour force surveys or population census data, with the restriction that they must be representative of the whole country, with no geographic limitation. More information on the construction of the estimates is given in Bourmpoula et al. (2015). These rates are positively correlated to within-survey employment rates, with a correlation coefficient of 0.299 with female unemployment rates in the DHS survey. Men's employment is less correlated (0.030) but this is not surprising because the quality of data on male unemployment in the DHS is low: it is collected in only 18 of our 31 countries, and where it is collected, it is missing in around $67 \%$ of cases.
} 
2005-2016, the study uses a longer time series going back to 1991 to model the trend in unemployment rates and, thereby, to extract the cyclical component of unemployment using a Hodrik-Prescott Filter (Hodrik and Prescott, 1997). ${ }^{24}$ The study also shows results with an alternative measure, the annual change in the logarithm of the unemployment rate.

Figure S1.1 a shows a plot of the cyclical male unemployment vs. cyclical female unemployment in the sample with a 45 degree line imposed on top. This shows that the unemployment shocks are positively correlated, although there is variation around the 45 degree line. Figure S1.1(b) displays the pooled (across countries) mean of cyclical and log-differenced male and female unemployment over time for the country-years in our sample. Although shocks to male and female unemployment are positively correlated (Figure S1.1(a)) ${ }^{25}$, shocks to female unemployment are larger and there is considerable variation in the relative size of each over time, as shown by the ratio and difference between the male and female cyclical unemployment (Figures S1.1(c) and S1.1(d)).

Figure S1.2(a) and (b) plot the unconditional association between country-year cyclical male and female unemployment and spousal physical violence rates. At the aggregate level, no clear pattern emerges from the data, particularly for female unemployment, though this unconditional association does not account for country fixed effects which the regression analysis shows it is important to account for (section 4).

\footnotetext{
${ }^{24}$ The stata command -tsfilter hp- is used, with a smoothing value of 6.25 which is the recommended value for yearly data. Our results are robust to using instead either 25 or 100 as alternative smoothing parameters.

${ }^{25}$ The correlation (covariance) between the aggregate cyclical male and female rates is $0.8463(0.015$, though note that the study uses variation within country over time in these series rather than cross-sectional variation). Though the sign of the shocks are often the same, this is not always the case and in a number of cases the sign of the shocks are opposing. Among examples are Dominican Republic in 2007, Malawi in 2010 and the Philippines in 2013. Co-movement of the two series is strongest in the later years in our sample (2014, 2015 and 2016). It has been confirmed that the results are robust to dropping these years from the analysis (results available on request).
} 


\section{Methodology}

\section{Baseline specification}

The equation of interest is:

$$
I P V_{i j t}=\alpha+\beta_{1} \ln U^{f}{ }_{j t-1}+\beta_{2} \ln U^{m}{ }_{j t-1}+\pi X_{i j t}+\gamma_{j}+\gamma_{t}+\varepsilon_{i j t}
$$

The dependent variable, $I P V_{i j t}$ is an indicator for whether a woman $\mathrm{i}$ in country $\mathrm{j}$ in interview year $t$ experienced intimate partner violence in the last twelve months. The variables of interest are $\ln U_{j t-1}^{f}$ and $\ln U^{m}{ }_{j t-1}$ which are de-trended log female and male unemployment in country $j$ in the previous year, respectively. ${ }^{26}$ In a robustness check, the study investigates replacing the de-trended rates with the first-difference of the rate.

The control variables $\mathrm{X}_{\mathrm{ijt}}$ in equation (1) include the education of the woman and her partner, her age, and an indicator for whether she resides in an urban location. For the sample for which it is available, religion is also controlled for. ${ }^{27}$ Country $\left(\gamma_{j}\right)$ and year $\left(\gamma_{t}\right)$ fixed effects are included to purge country-level unobservables and common shocks respectively. The study does not include country specific trends in the main specification since unemployment is already de-trended. However, the study checks robustness of the results to the inclusion of country-specific trends. Standard errors are robust to arbitrary forms of heteroscedasticity and are clustered at the country level. The study estimates linear probability models using OLS.

\footnotetext{
${ }^{26}$ The study uses lags because surveys conducted in year t query violence in the twelve months up until t, which is contemporaneous with unemployment shocks in $\mathrm{t}-1$.

${ }^{27}$ Religion is missing for $34.4 \%$ of the sample, since information on religion is not collected in 13 of our surveys; including all surveys for Colombia, Jordan, Kyrgyz Republic, Pakistan, Peru, Tajikistan and Tanzania, and for one survey in the Dominican Republic (2007). Amongst surveys for which information on religion is recorded, it is missing for less than $1 \%$ of observations. The study chooses to drop missing observations rather than, for example, choosing to code missing values under a new variable (i.e. an indicator for missing religion) due to concerns that inclusion of such a variable can bias estimates (Jones, 1996). The study shows robustness to the religion control for the subsample for which it is available.
} 


\section{Heterogeneity by gender equality in access to divorce}

The study investigates whether the observed association differs between countries in which women face more legal, financial, customary or religious barriers in access to divorce than men. It uses the OECD 2019 Social Institutions Gender Index (SIGI) which contains a measure of this. The study estimates the main specifications for subsamples defined by whether or not men and women have the same rights to initiate and finalise divorce (see Table S1.2 for details of these samples, as well as comparison with the UK and US as the study referred to studies of these countries earlier). ${ }^{28,29}$

\section{Results}

\section{Baseline specification}

The study shows estimates of equation (1) for each indicator of IPV, with controls sequentially added (Table 1). The study first presents the unconditional correlation, which is negative for male unemployment and insignificantly small for female unemployment, mirroring the association observed in the raw data in Figure S1.3. The estimates are not sensitive to inclusion of year fixed effects. However, they are sensitive to inclusion of country fixed effects, consistent with time-invariant country-level characteristics being correlated with both IPV and unemployment rates. Once country fixed effects are in, the estimates are not sensitive to covariates.

\footnotetext{
${ }^{28}$ Equality in access to divorce is defined in the SIGI as "Women have both the same rights to initiate divorce and the same requirements to finalise divorce or annulment as men, without negative repercussions on their parental authority. This applies to all groups of women. Customary, religious and traditional laws or practices do not discriminate against women's rights regarding divorce or parental authority after divorce" (source: https://www.genderindex.org/data/)

${ }^{29}$ Variation in access to divorce may also pick up the variation in social acceptability of divorce. The study cross-checked this using data from the World Values Survey (WVS), available for 19 countries in the sample. In the sample with equal access, the average score for social acceptability is 4.28 , while in the sample where women have weaker access to divorce, the social acceptability score is 3.53 . Note that social acceptability is scored 1 to 10 , where 1 indicates that divorce is never justifiable, 10 indicates it is always justifiable and the average across the (19) DHS countries for whom WVS data is available is 3.68 while the average over the UK and the US is 6.03 .
} 
In the preferred specification, conditional on country and year effects and covariates, an increase in male unemployment rates, holding female unemployment constant, is associated with increases in the incidence of physical violence. In contrast, an increase in female unemployment rates, holding male unemployment constant, is associated with reductions in the incidence of physical violence (column 4 of Panel A, Table 1). The coefficients for sexual violence are of the same sign but are not statistically significant once the study includes all controls (Panel B, Table 1). Results for physical and sexual violence (Panel C, Table 1) are driven by physical violence. An F-test of equality comfortably rejects the null that the coefficients on $\ln U^{f}{ }_{j t-1}$ and $\ln U^{m}{ }_{j t-1}$ are equal. ${ }^{30}$ There is no robust statistically significant association between the total (male plus female) unemployment rate and IPV (Table S1.3), a finding also shown in Anderberg et al (2016). ${ }^{31}$

A potential concern is that the estimates for male and female unemployment are driven by multicollinearity. However, the precision of our estimates speaks against multicollinearity. ${ }^{32}$ In order for the study to mistake the sign on the coefficients of interest, the standard errors would have to be large enough to encompass the "true" effect with the opposite sign. In this setting this is not the case. Still, to investigate this further, the study estimates an alternative specification that includes the total (male plus female) unemployment rate and the ratio of the female to the male unemployment rate. The study finds that it is the ratio rather than common shocks which influence IPV (see Section 5 below).

Holding female unemployment rates constant, a rise in male unemployment relative to trend by one percent is associated with an increase in the probability that a woman is a victim of physical violence by 0.50 percentage points, or an increase of 50 cases per 10,000 (Table 1, Panel A, Column

\footnotetext{
${ }^{30}$ The finding that male and female unemployment shocks have opposing influences on IPV allows us to set aside concerns about all confounders that have same-signed correlations with male and female unemployment rates.

${ }^{31}$ In the sexual violence specification, the unconditional correlation of total unemployment is significant, but this is not robust to the inclusion of country fixed effects. In all other cases the coefficient is statistically insignificant.

32 The authors are grateful to the Editor for this insight.
} 
(4)). This translates to $2.75 \%$ of the mean prevalence rate of physical violence in the sample. An upswing in female unemployment from trend of one percent is associated with the risks of physical violence decreasing by 0.52 percentage points, or a decrease of 52 cases per 10,000 (Table 1, Panel A, Column (4)). This translates to $2.86 \%$ of the mean prevalence rate of physical violence in the sample. The study find no statistically significant effects for sexual violence. ${ }^{33,34}$

The finding that men react adversely to improvements in women's employment prospects conditional upon their own is consistent with models of male-backlash (Macmillan and Gartner 1999, Akerlof and Kranton, 2000). When men feel traditional gender roles (male breadwinner) being threatened through elevation of women's relative status, they react negatively, attempting to reassert their authority through violence or other means. Evidence consistent with this has been found in other domains, in studies not concerned with domestic violence (Schuler et al 1996, Atkinson et al. 2005, Mani 2011, Gagliarducci and Paserman 2012, Gangadharan et al 2015).

The study now consider how the identified effect sizes compare with previous studies. The results for male and female unemployment are very similar in magnitude to those found by Tur-Prats (2017), who finds that a one percent increase in female (male) unemployment in Spain is associated with a decrease (increase) in risk of experiencing violence by $0.56(0.37)$ percentage points, amongst provinces in which local historical gender identity norms prescribed men as main contributors to the household income. The effects estimates in this study are larger and, for female employment, of

\footnotetext{
${ }^{33} \mathrm{~A}$ rise in female unemployment from trend by one percent is also associated with the risk of physical and/or sexual violence decreasing by 0.58 percentage points, or a decrease of 58 cases per 10,000 . This translates to $2.93 \%$ of the mean prevalence of physical and/or sexual violence in the sample. Driven by the effects on physical violence, a rise in male unemployment relative to trend by one percent is also associated with an increase in the probability that a woman is a victim of physical and/or sexual violence by 0.53 percentage points, or an increase of 53 cases per 10,000. This translates to $2.66 \%$ of the mean prevalence of physical and/or sexual violence in the sample.

${ }^{34}$ In an extension of the main analysis, the study investigated whether IPV today is a function of unemployment rates in the year of marriage. If unemployment in the year of marriage determines selection on the marriage market (i.e. who an individual marries), then it may be the case that unemployment in year of marriage determines IPV-patterns (or power balance) within a marriage. However, the study found no statistically significant effects (results available on request).
} 
opposite sign to those reported by Anderberg et al. (2016) for the UK, who find that a 1 percentage point increase in female unemployment (holding male unemployment constant) is associated with an increase in the risk of experiencing IPV of 0.097 percentage points. Like this study they find that male unemployment rates have an effect of similar magnitude but opposite-sign, a 1 ppt increase leading to a decrease in IPV of $0.090 \mathrm{ppt}^{35}$ As discussed in the Introduction, they motivate their results with a model in which, when women have improved outside options (higher employment prospects), and the possibility of dissolution of the marriage union, men have an incentive to tame any tendency towards violence. ${ }^{36}$ In section 4.2 , the study considers whether the observed associations differ between countries in which women can access divorce similarly to men, and countries in which they cannot.

The study also compares its estimates with estimates from studies of domestic violence that investigate other causes. For instance, it is estimated that availability of alcohol raises intimate partner violence by 5 percentage points in India (Luca et al. (2017)), that public transfers (Mexico's Opportunidades program) lower incidence of IPV by 8.2 percentage points (Bobonis et al., 2013), and that a one standard deviation in civil conflict intensity in a respondent's place of residence raises physical IPV by 5.07 percentage points in Rwanda (La Mattina, 2017).

Heterogeneity by an indicator of gender equality in access to divorce

\footnotetext{
${ }^{35}$ Indeed, this is consistent with evidence that relaxation of divorce laws can lead to a reduction in domestic violence due to the resulting change in bargaining power within the household (Stevenson and Wolfers, 2006; Brassiola, 2016). However, here, the study argues that social norms in many of the countries in the sample limit the extent to which divorce can act as a margin for women so that men are less likely to be "tamed" by the threat of divorce, explaining the opposite signed result for low income countries.

${ }^{36}$ In the UK and other OECD countries, the fact that divorce is a real option (and not uncommon) implies endogenous changes in the composition of surviving marriages. In other words, if the most violent partnerships dissolve, IPV will be measured on a lower risk sample. Schaller (2013) and Stevenson and Wolfers (2016) present evidence for the United States that divorce (like marriage) is pro-cyclical. However there is contrasting evidence from the UK, showing that unexpected improvements in financial circumstances lower the risk of divorce (Böheim and Ermish, 2001). If one thinks of divorce as a limiting case for domestic violence, then one might imagine that business cycle variation in divorce proxies business cycle variation in domestic violence. However, the relationship may flip if the costs of divorce are high
} 
The estimates show a striking separation, showing that the associations observed in Table 1 are driven entirely by the sample in which women do not have equal access to divorce. For this sample, the estimates are remarkably similar to those in Table 1: A rise in male unemployment relative to trend of one percent is associated with an increase in the probability that a woman is a victim of physical violence of 0.56 percentage points, or an increase of 56 cases per 10,000 (Table 2, Panel A, Column (4)). An upswing in female unemployment from trend of one percent is associated with the risks of physical violence decreasing by 0.52 percentage points, or a decrease of 52 cases per 10,000 (Table 2 , Panel A, Column (4)). In contrast, in countries in which women have equal access to divorce (as in countries such as the US and UK), the study finds the opposite signed effects. Results for these countries align with those in Anderberg et al (2016) for the UK.

\section{Robustness checks}

Here, the study discusses robustness of its results to the inclusion of country-specific trends, alternate specifications in which it replaces the cyclical component of the logarithm of the two gender specific unemployment rates with the first difference in the logarithms of these rates, and a specification that includes the total unemployment rate alongside the ratio of male and female unemployment rather than the two rates independently. The study also consider robustness of its results to sample composition, and alternative measurements of IPV.

The study's findings are robust to including country-specific trends (Table 3). For physical violence, the coefficients are attenuated but retain significance. Using the original measure of the business cycle (the cyclical component), the study continues to find no statistically significant coefficients for changes in male or female unemployment on sexual violence. The study replaced detrended log female and male unemployment in equation (1) with the (lagged) first difference in the logarithm of the unemployment rate:

$$
I P V_{i j t}=\alpha+\beta_{1} \Delta \ln u_{i j t}^{f}+\beta_{2} \Delta \ln u_{i j t}^{m}+\pi X_{i j t}+\gamma_{j}+\gamma_{t}+\gamma_{j} t+\varepsilon_{i j t}
$$


The results point in the same direction (see Table 4). Increases in male unemployment are associated with increased physical violence against women and increases in female unemployment with decreases.

Next, the study replaces the male and female unemployment rates with the total (male plus female) unemployment and the ratio of the male to female unemployment rate. The first term captures common variation in the two rates, reflecting general economic conditions, while the second captures divergence between male and female employment opportunities. The ratio was shown in Figure S1.2(c) to exhibit substantial variation over time. For both terms the study uses cyclical components of the series as before.

$$
I P V_{i j t}=\alpha+\beta_{1} \ln U_{j t-1}+\beta_{2} \ln \left(\frac{U^{m}}{U^{f}}\right)_{j t-1}+\pi X_{i j t}+\gamma_{j}+\gamma_{t}+\varepsilon_{i j t}
$$

The results, in Table 5, suggest no statistically significant association between total cyclical unemployment and IPV, for which the study finds a very small estimated coefficient close to zero. However, an increase in the ratio of the male to the female unemployment rate of one percent is associated with a rise in the risk of physical violence of 0.50 percentage points.

The study checked whether sample composition drives the results in two ways. Since the preferred specification in Table 1 (column (V)) identifies the relationship from the 21 countries for which the study has multiple years of data, it re- estimates equation (1) on the subsample of countries for which it observes women in at least two years. The results are almost identical (Table S1.4). Second, since $23.3 \%$ of the sample of women are Indian and $20.4 \%$ Colombian, one concern might be that these countries are driving the observed effects. In fact, the study finds this is not the case. Figures $2 \mathrm{a}-2 \mathrm{~b}$, and $\mathrm{A} 4$, generalize this, showing the estimated coefficients when the study drops one country at a time from the sample, and re-estimates. Overall the estimates are robust to changes in sample composition. 
The main specification measures IPV as dummy variables, taking the value of one if the woman has ever faced i) physical, ii) sexual or iii) any form of violence from her partner. As an alternative, the study aggregates information from the underlying questions on specific acts of IPV into summary indices, since this aggregation can improve statistical power to detect effects that go in the same direction within a domain (Kling et al. 2007). The study firsts convert answers to individual physical violence and sexual violence questions to z-scores by subtracting the country-specific mean and dividing by the country-specific standard deviation, for each of the individual questions on physical and sexual violence. The study then averages over these z-scores to create an index for i) physical violence, ii) sexual violence, as in Erten and Keskin (2018). Finally, it creates an index for iii) any violence, which is the arithmetic mean of the physical and sexual violence indices. Results in Table S1.5 show that the results are robust to using indices of violence, and gain statistical significance when considering sexual violence (Panel B), which now becomes statistically significant. Overall, the results are qualitatively similar and confirm the main analysis.

Finally, the study investigated the association of domestic violence with the (potentially endogenous) individual unemployment status of the woman and her partner, using questions in the DHS that ask whether the individual worked in the last 12 months. This acts as a consistency check on the main analysis. A caveat is that male unemployment is measured poorly in the DHS data - it is collected in only 18 of our 31 countries $^{37}$, and even where it is collected, it is missing in around 67\% of cases. Still, the pattern of results for individual unemployment mirrors the pattern for unemployment rates (Table S1.6). Holding constant the unemployment status of their spouse, female unemployment in the last 12 months is associated with lower incidence of spousal violence. Male

\footnotetext{
${ }^{37}$ This discrepancy in availability across countries is due to the fact that women are not asked about the employment status of their partners. Information on spousal unemployment is only available for surveys in which a men's survey is collected, which is not the case in all countries.
} 
(spousal) unemployment is associated with a higher incidence of violence, although this is not statistically significant in every specification.

\section{Discussion and Conclusion}

The literature has considered alternative explanations for why men perpetrate violence against women partners. Among these are that men gain self-esteem or an enhanced sense of control from committing violence (Farmer and Tiefenthaler, 1997); that they have strategic motivations, such as to use violence to extract resources from the woman or her family (Bloch and Rao, 2002); and that violence occurs almost inadvertently in response to emotional cues (Card and Dahl, 2011). Other studies have highlighted psychological drivers of abuse such as a history of childhood trauma, personality and relationship dysfunctionality (Heise and Kotsadam, 2015), or early life exposure to domestic violence (Pollak 2004). Finally, there are studies showing that regional variation in IPV today reflects cultural factors rooted in historical customs (Alesina et al. 2016; Tur Prats 2015).

This paper used comparable and representative repeated cross-sections of survey data from up to thirty one countries containing women's reports of violence committed against them in the preceding year. It identified a systematic contemporaneous association of unemployment shocks with interpersonal violence. The study finds that changes in male and female unemployment rates have opposing association with IPV; these associations are large, at between $2.75-2.86 \%$ of the mean IPV prevalence rates in the sample. However, they are smaller than the estimates obtained by studies on the impact of alcohol on IPV (Luca et al., 2017). Interpersonal violence is higher when men are more likely to be unemployed and, holding constant male unemployment rates, it is higher if women face improved employment probabilities.

These findings contrast sharply with recent results for the US and the UK (Aizer 2010, Anderberg et al. 2015) where IPV has been seen to be decreasing in the gender wage gap and in increased employment rates of women respectively. These are countries in which women's labour 
force participation has risen considerably in past decades and stabilized, weakening the male breadwinner norm, and in which women have much more freedom to exit partnerships. When the study separates the sample into those countries where men and women have equal access to divorce and those where women's access is lower, it finds that the results for the former are similar to those obtained by Anderberg et al (2015) and Aizer (2010). In a majority of developing countries, however, patriarchal norms are much stronger, inequality in access to divorce persists, and women's employment is still on the rise, creating a potential clash between economic changes and norms, which may increase the probability of violence.

In addition to the income effects of male unemployment and female employment, there may also be psychological responses driven by social norms. The finding that increases in male unemployment rates lead to increased violence against women is consistent with the stresses of financial insecurity since unemployment of men challenges income security of the family, and previous research shows that cash transfers reduce IPV (see e.g. Hidrobo et al. 2016). It is also consistent with psychic costs of unemployment, this being larger for men who grow up with the expectation that they will be the providers (Tur-Prats, 2017). However the finding that women are more likely to be subject to violence from a partner when employment prospects for women improve is almost certainly a psychic responses, as established in previous research on backlash (since improved employment chances for women reduce financial stress, the study can reject that the income channel is at play for this result). ${ }^{38}$ These findings also reject the 'exposure reduction' model which predicts increasing violence in response to both male and female unemployment, explained by unemployment increasing time spent together, which is assumed to increase the potential for conflict (Dugan et al. 1999, YooMi Chin (2012)).

\footnotetext{
${ }^{38}$ Recall that the thought experiment simulated by the regression model is that women's employment prospects change with men's prospects held constant.
} 
While the evidence in this paper is descriptive, the estimated conditional correlations suggest that the standard bargaining model, which emphasizes how the power balance within the household is sensitive to outside options, may be of more limited empirical significance in poorer countries where the outside option is not readily exercised because of explicit (legal) and implicit (social) constraints. In her seminal analysis of IPV in the United States, Aizer (2010) challenges the backlash hypothesis as being problematic because it "ignores the individual rationality constraints faced by women in abusive relationships... as their income increases, women are more likely to end the partnership if transfers decline and abuse continues". The evidence is that in many developing countries, women do not have the financial means or the social support to end partnerships. Indeed, a stylized fact concerning IPV on a global scale is that it tends to repeat within a couple, suggesting that across the world, women do not readily leave a relationship once subject to violence (Davis and Taylor 1997; Woodhouse and Dempsey 2016). However the perception (on the part of both men and women) that they can may still be effective.

The results of this study are topical given strong global trends in married women's labour force participation in many parts of the world. In Latin America, many countries, including Mexico and Brazil, have witnessed large increases (ILO 2016). Although the large increases in married women's work participation in richer countries occurred earlier, there is contemporary business cycle variation in the relative participation rates of men and women. In particular, the recent recession has hit men harder than women, narrowing the gender gap. There is a similar tendency in poorer countries, driven by subsistence targets strengthening the added worker effect. In other words, women who may otherwise not work tend to take work in recessions in order to make up for the decline in male income (Bhalotra and Umana-Aponte 2010).

A recent UN publication outlining a framework to reduce violence against women suggests a range of potential approaches, including the empowerment of women and the changing of social norms to foster mutual respect between men and women (UN Women, 2015b). These results show 
that simply increasing employment opportunities for women, as done by several microcredit programmes in developing countries, may backfire. Indeed, the literature shows that women often draw smaller profits from micro-enterprise than men, and one explanation for this has been the existence of inefficient (non-cooperative) models of the household (e.g. De Mel et al. 2009). This has not been previously considered but the results of this study suggest that adverse male reactions to loans targeting women may play a role. ${ }^{39}$ Future work should look more carefully at whether implementing women's rights across multiple domains including property rights, custodial rights and divorce may better protect against IPV. Community empowerment approaches that attempt to change social norms may generate sustained reductions in IPV (More et al. 2017).

\footnotetext{
${ }^{39}$ The authors are grateful to the Editor, Eric Edmonds for this suggestion.
} 


\section{References:}

Aizer, A. (2010). “The Gender Wage Gap and Domestic Violence.” American Economic Review, 100(4): 1847-59

Aizer, A. (2011) "Poverty, Violence, and Health: The Impact of Domestic Violence During Pregnancy on Newborn Health." Journal of Human Resources 46, no. 3: 518-538.

Agarwal, B. (1994) “A Field of One's Own: Gender and Land Rights in South Asia”, Cambridge University Press

Agüero, J. M., and V. Frisancho (2017). "Misreporting in Sensitive Health Behaviors and Its Impact on Treatment Effects: An Application to Intimate Partner Violence." Inter-American Development Bank.

Akerlof, G. A., and R. E. Kranton (2000). "Economics and identity." The Quarterly Journal of Economics, 115(3), 715-753.

Alesina, A., B. Brioschi, and E. L. Ferrara (2016). "Violence against women: A cross-cultural analysis for Africa." NBER Working Paper No. 21901

Alonso-Borrego, C., and R. Carrasco. (2017). "Employment and the risk of domestic violence: does the breadwinner's gender matter?” Applied Economics, 1-18.

Anderberg, D., H. Rainer, J. Wadsworth, and T. Wilson, (2016), "Unemployment and Domestic Violence: Theory and Evidence." The Economic Journal, 126: 1947-1979.

Anderson, S, and E. Mukesh (2009), "What determines female autonomy? Evidence from Bangladesh." Journal of Development Economics, no. 2: 179-191.

Angelucci, M. (2008). "Love on the rocks: Domestic violence and alcohol abuse in rural Mexico." The BE Journal of Economic Analysis \& Policy, 8(1).

Atkinson, M. P., T. N. Greenstein, and M. M. Lang (2005). "For women, breadwinning can be dangerous: Gendered resource theory and wife abuse." Journal of Marriage and Family, 67(5), 11371148.

Ashraf, N, E. Field, and J. Lee. (2014). "Household Bargaining and Excess Fertility: An Experimental Study in Zambia." American Economic Review, 104(7): 2210-37

Baranov, V., S. R. Bhalotra, P. Biroli, and J. Maselko (2017). "Maternal Depression, Women's Empowerment, and Parental Investment: Evidence from a Large Randomized Control Trial." IZA Discussion Paper No. 11187

Bertrand, M., E. Kamenica, and J. Pan (2015). "Gender identity and relative income within households." The Quarterly Journal of Economics, 130(2), 571-614.

Bhalotra, S., and M. Umaña-Aponte. (2015). "Women's labour supply and household insurance in Africa." Growth and Institutions in African Development, 117-351.

Amaral, S., S. Bhalotra, and N. Prakash (2018). "Crime and punishment: Women police stations in India." Mimeo.

Blattman, C., and E. Miguel. (2010). “Civil war.” Journal of Economic literature, 48(1), 3-57.

Bloch, F, and V. Rao. (2002). "Terror as a Bargaining Instrument: A Case Study of Dowry Violence in Rural India." American Economic Review, 92(4): 1029-1043. 
Bobonis, G. J., M. González-Brenes, and R. Castro. (2013). "Public transfers and domestic violence: The roles of private information and spousal control." American Economic Journal: Economic Policy, 5(1), 179-205.

Böheim, R., and J. Ermisch. (2001) "Partnership dissolution in the UK-the role of economic circumstances." Oxford Bulletin of Economics and Statistics 63, no. 2: 197-208.

Bourmpoula, V., S. Kapsos, and J. M. Pasteels, (2015) ILO labour force estimates and projections: 1990-2050 (2015 edition), ILO Geneva

Bowlus, A. J., and S. Seitz. (2006). "Domestic violence, employment, and divorce." International Economic Review, 47(4), 1113-1149.

Brassiolo, P. (2016). "Domestic violence and divorce law: When divorce threats become credible." Journal of Labor Economics, 34(2), 443-477.

Card, D., and G. B. Dahl. (2011). "Family violence and football: The effect of unexpected emotional cues on violent behavior." The Quarterly Journal of Economics 126, no. 1: 103.

Chin, Y., (2012), "Male backlash, bargaining, or exposure reduction?: women's working status and physical spousal violence in India." Journal of Population Economics, 25, issue 1, p. 175-200.

Dahl, G. B., and E. Moretti. (2008) “The demand for sons." The Review of Economic Studies 75, no. 4 p. 1085-1120.

Davis, R.C. and B. G. Taylor. (1997). "A proactive response to family violence: The results of a randomized experiment." Criminology, 35(2), p. 307-333.

De Mel, S., D. McKenzie, and C. Woodruff. (2009). "Are women more credit constrained? Experimental evidence on gender and microenterprise returns." American Economic Journal: Applied Economics, 1(3), 1-32.

Devries KM, J.Y. Mak, C. García-Moreno, M. Petzold, J.C. Child, G. Falder, S. Lim, L.J. Bacchus, R.E. Engell, L. Rosenfeld, C. Pallitto, T. Vos, N. Abrahams, C. H. Watts (2013) "The global prevalence of intimate partner violence against women. "Science 340, no. 6140: 1527-1528.

Dugan, L., D. S. Nagin, and R. Rosenfeld. (1999). "Explaining the decline in intimate partner homicide: The effects of changing domesticity, women's status, and domestic violence resources." Homicide Studies, 3(3), pp.187-214.

Eaton, J., S. Kortum, B. Neiman and J. Romalis. (2016). "Trade and the global recession.” American Economic Review, 106(11), 3401-3438.

Erten, B., and P. Keskin. (2018). "For Better or for Worse?: Education and the Prevalence of Domestic Violence in Turkey". American Economic Journal: Applied Economics, 10(1): 64-105.

Farmer, A., and J. Tiefenthaler. (1997), "An Economic Analysis of Domestic Violence”, Review of Social Economy, 55, issue 3, p. 337-358.

Gangadharan, L., T. Jain, P. Maitra, and J. Vecci. (2016). "Social identity and governance: The behavioral response to female leaders." European Economic Review, 90, 302-325.

Gagliarducci, S. and D. Paserman. 2012. "Gender Interactions within Hierarchies: Evidence from the Political Arena." Review of Economic Studies 79(3): 1021-1052.

Gulesci, S., E. Meyersson, and S. Trommlerová (2019). "The effect of compulsory schooling expansion on mothers' attitudes towards domestic violence in Turkey." World Bank Economic Review. https://doi.org/10.1093/wber/lhy021 
Hidrobo, M., A. Peterman and L. Heise. (2016). "The effect of cash, vouchers, and food transfers on intimate partner violence: evidence from a randomized experiment in Northern Ecuador." American Economic Journal: Applied Economics, 8(3), 284-303.

Heise, L. L., and A. Kotsadam (2015). "Cross-national and multilevel correlates of partner violence: an analysis of data from population-based surveys." The Lancet Global Health, 3(6), e332-e340.

Hodrick, R. J., and E. C. Prescott. (1997). "Postwar US business cycles: an empirical investigation." Journal of Money, Credit, and Banking : 1-16.

International Labour Organisation (ILO). (2016). Women at work: trends 2016

Jones, M. P. (1996). Indicator and stratification methods for missing explanatory variables in multiple linear regression." Journal of the American statistical association, 91(433), 222-230.

Kishor, S. and K. Johnson. "Profiling domestic violence: a multi-country study." (2004). OCR Macro

Kling, J. R., J. B. Liebman, and Katz, L. F. (2007). "Experimental analysis of neighborhood effects." Econometrica, 75(1), 83-119.

La Mattina, G. (2017). "Civil conflict, domestic violence and intra-household bargaining in postgenocide Rwanda. " Journal of Development Economics, 124, 168-198.

Luca, D. L., E. Owens, and G. Sharma. (2017). “The Effectiveness and Effects of Alcohol Regulation: Evidence from India." Mimeograph.

Luke, N. and K. Munshi. (2011). "Women as Agents of Change: Female Income and Mobility in India." Journal of Development Economics 94(1):1-17.

Macmillan, R. and R. Gartner. (1999). "When She Brings Home the Bacon: Labor Force Participation and the Risk of Spousal Violence Against Women." Journal of Marriage and the Family, 61(4):947-958.

Mani, A. (2011). "Mine, yours or ours? The efficiency of household investment decisions: an experimental approach. " Working Paper. Coventry, UK: Department of Economics, University of Warwick. (CAGE Online Working Paper Series).

Mani, A., L. Iyer, P. Mishra and P. Topalova (2012). "The Power of Political Voice: Women's

Political Representation and Crime in India." American Economic Journal: Applied Economics 4(4): 165-

193, October.

Michau, L., J. Horn, A. Bank, M. Dutt, and C. Zimmerman (2015) "Prevention of violence against women and girls: lessons from practice". The Lancet 385, no. 9978: 1672-1684.

Milazzo, A. (2014). "Why Are Adult Women Missing? Son Preference and Maternal Survival in India" World Bank Policy Research Working Paper 6802.

More, N. S., S. Das, U. Bapat, G. Alcock, S. Manjrekar, V. Kamble, R. Sawant, S. Shende, N. Daruwalla, S. Pantvaidya, D. Osrin (2017) "Community resource centres to improve the health of women and children in informal settlements in Mumbai: a cluster-randomised, controlled trial". The Lancet Global Health, 5(3), e335-e349.

OECD Development Centre (2014). Social Institutions and Gender Index (SIGI) 2014 Synthesis Report.

Pollak, R. A. (2004) “An intergenerational model of domestic violence." Journal of Population Economics 17, no. 2: 311-329. 
Pronyk, P.M., J. R. Hargreaves, J.C. Kim, L.A. Morison, G. Phetla, C. Watts, J. Busza, and J.D. Porter, 2006. "Effect of a structural intervention for the prevention of intimate-partner violence and HIV in rural South Africa: a cluster randomised trial.” The Lancet, 368(9551), pp.1973-1983.

Rawlings, S. and Z. Siddique. (2018) "Domestic Abuse and Child Mortality." IZA Discussion Paper No. 11899

Schaller, J. (2013) "For richer, if not for poorer? Marriage and divorce over the business cycle. "Journal of Population Economics 26, no. 3: 1007-1033.

Schuler, S. R., L.M. Bates, and F. Islam. (2008). "Women's rights, domestic violence, and recourse seeking in rural Bangladesh". Violence Against Women, 14(3), 326-345.

Schuler, S. R., S. M. Hashemi, A. P. Riley, and S. Akhter. (1996). "Credit programs, patriarchy and men's violence against women in rural Bangladesh". Social Science \& Medicine, 43(12), 1729-1742.

Stevenson, B., \& Wolfers, J. (2006). "Bargaining in the shadow of the law: Divorce laws and family distress." The Quarterly Journal of Economics, 121(1), 267-288.

Stevenson, B., \& Wolfers, J. (2016). "The Economics of Divorce”. Annual Review of Economics, 8(1).

Tauchen, H. V., A. D. Witte, and S. K. Long (1991). "Domestic violence: A nonrandom affair." International Economic Review, 491-511.

Tertilt, M., and G. J. Berg. (2015). "The association between own unemployment and violence victimization among female youths." Journal of Economics and Statistics, 235(4-5), 499-516.

Tur-Prats, A. (2015). "Family Types and Intimate- Partner Violence: A Historical Perspective". Working Papers 835, Barcelona Graduate School of Economics.

Tur-Prats, Ana. (2017) "Unemployment and intimate-partner violence: A gender-identity approach". UPF working paper No. 1564.

Woodhouse, J. and N. Dempsey, 2016, "Domestic Violence in England and Wales” Briefing Paper No. 6337, House of Commons Library

UN Women (2015a) "Monitoring Gender Equality and the Empowerment of Women and Girls in the 2030 Agenda for Sustainable Development: Opportunities and Challenges"

http://www.unwomen.org/en/digital-library/publications/2015/9/indicators-positionpaper\#sthash.TicCeB2P.dpuf

UN (2015b) "The sustainable development goals. Goal 5: Achieve gender equality and empower all women and girls" http://www.un.org/sustainabledevelopment/gender-equality/

UN Women (2015c) “A framework to underpin action to prevent violence against women"

http://www.unwomen.org/en/digital-library/publications/2015/11/preventionframework\#sthash.UUhyVCWX.dpuf

WHO (2014). “Global status report on violence prevention” World Health Organization

World Bank (2012) “World Development Report 2012 : Gender Equality and Development”. World Bank. 


\section{$\underline{\text { Tables and Figures }}$}

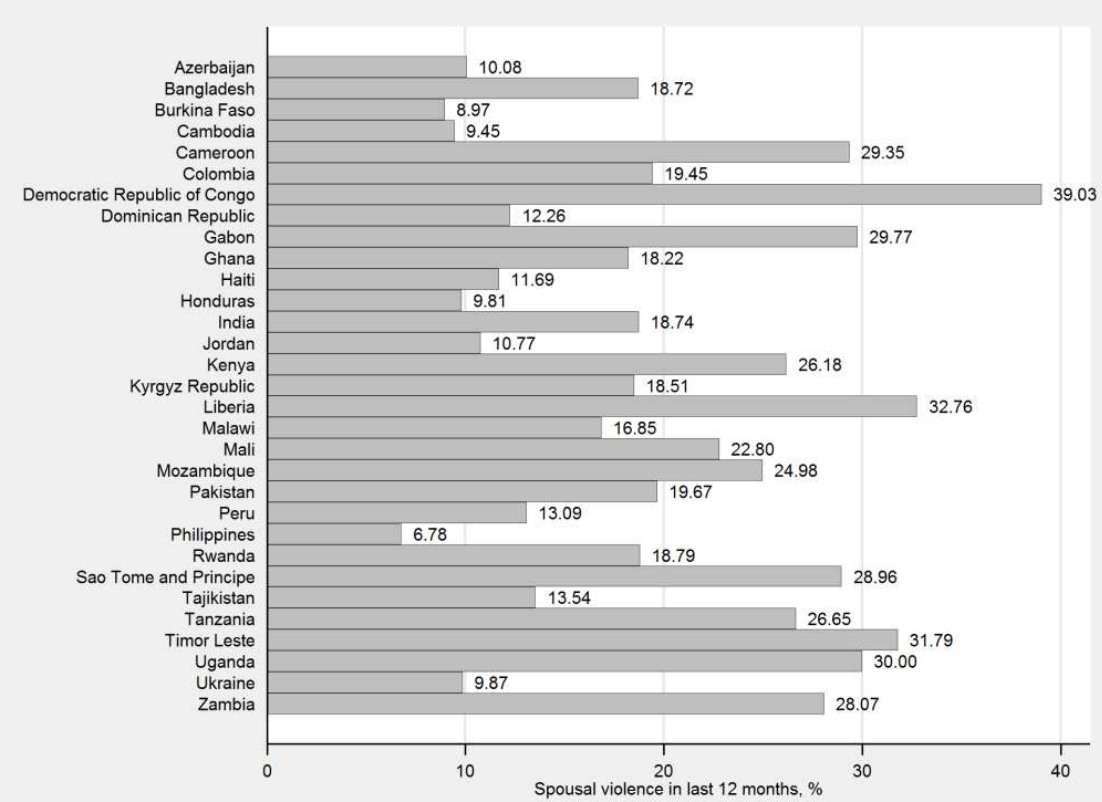

Figure 1a: Incidence of physical violence across countries

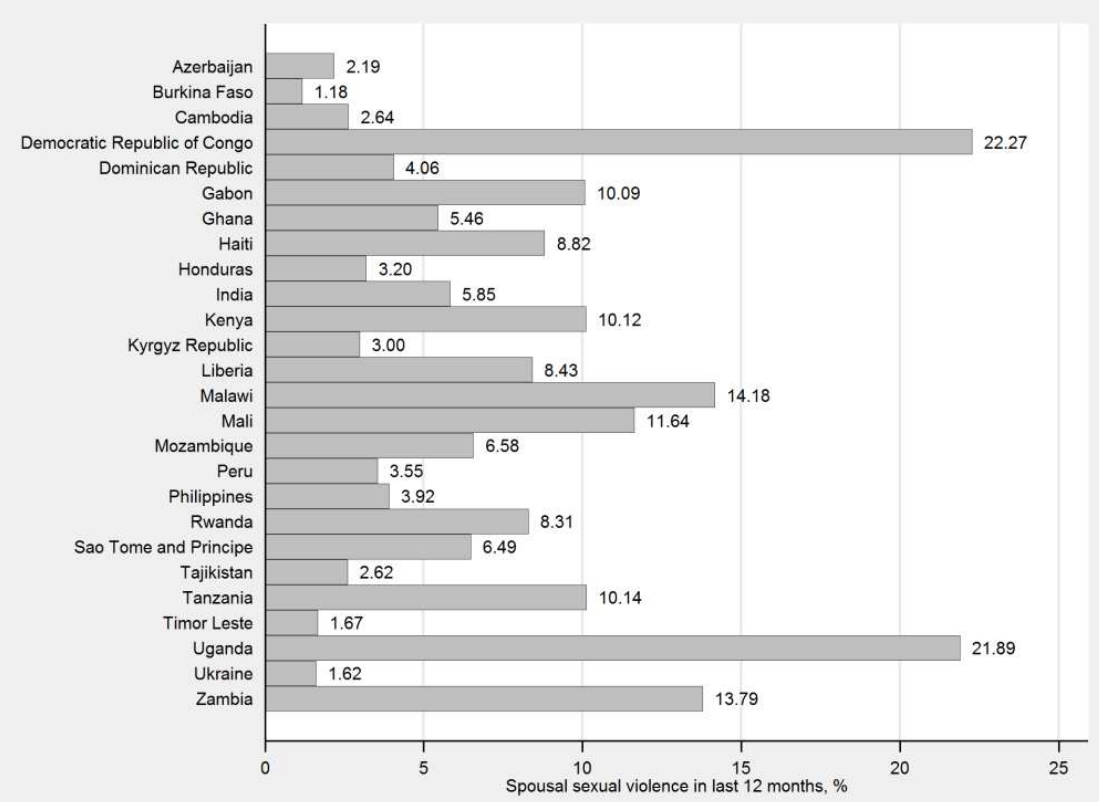

Figure 1b: Incidence of sexual violence across countries

Source: Authors' analysis based on data from the Demographic and Health Surveys (DHS).

Notes:

Figures show the percentage of women who reported experiencing a) physical and b) sexual violence from their partner in the last 12 months. 


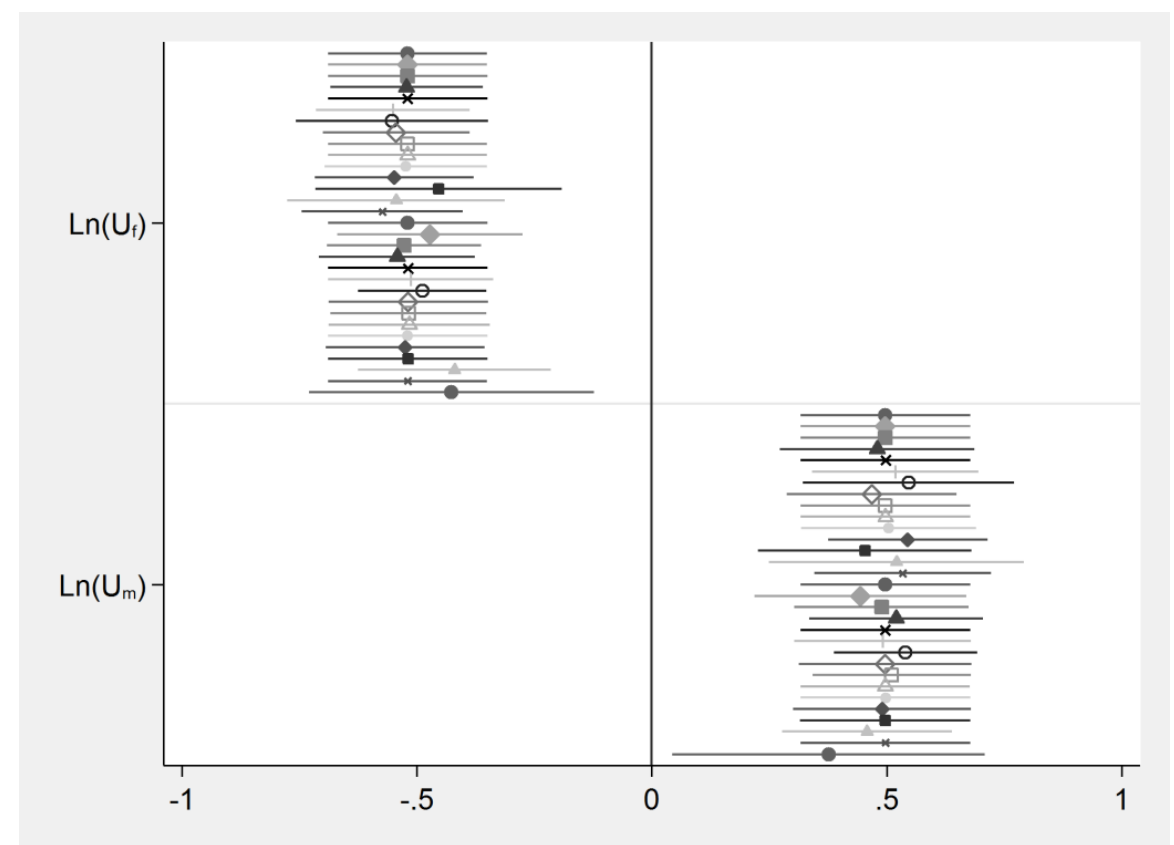

Figure 2a: Variation in estimated coefficients across sample - physical violence

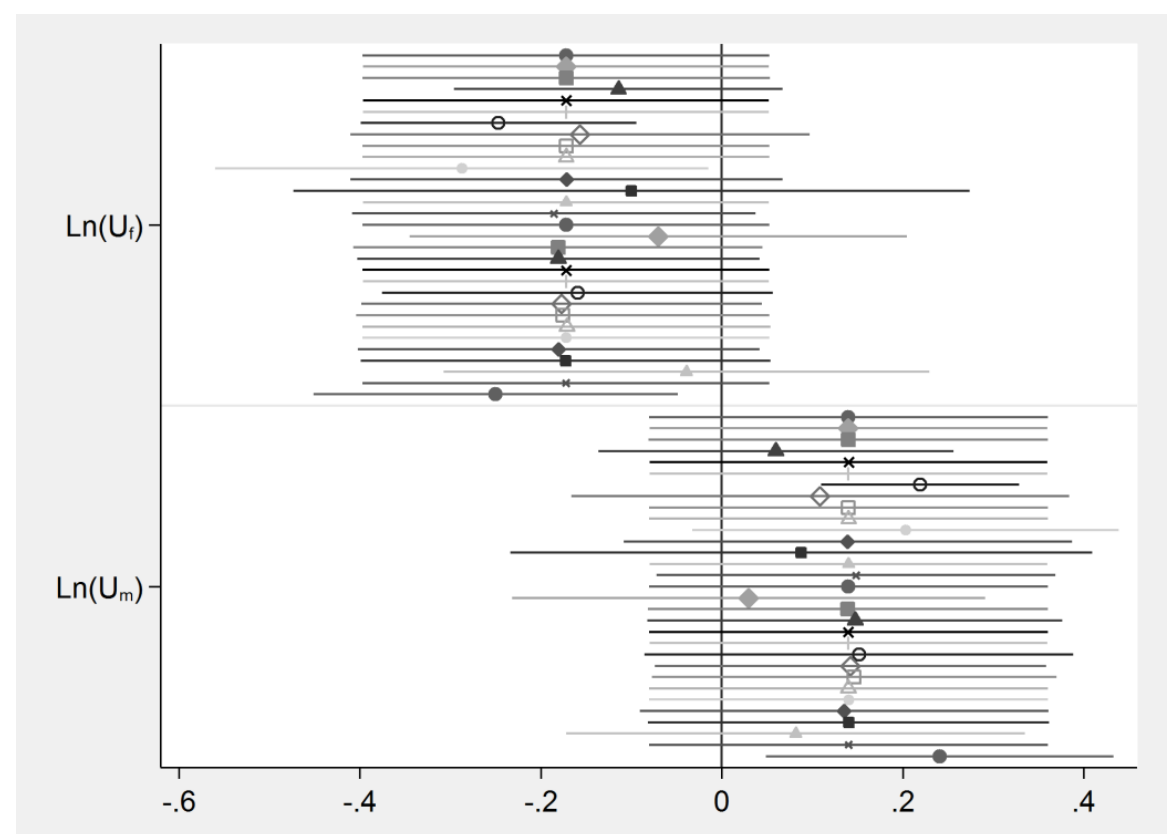

Figure 2b: Variation in estimated coefficients across sample - sexual violence Source: Authors' analysis based on data from the Demographic and Health Surveys (DHS).

Notes:

Figures show estimated coefficients from a leave one out analysis, with $95 \%$ confidence intervals. Estimations include individual level controls, and country and year fixed effects. 
Table 1: Impact of cyclical fluctuations in male and female unemployment rates on IPV

\begin{tabular}{|c|c|c|c|c|c|c|}
\hline & \multicolumn{4}{|c|}{ Main Sample } & \multicolumn{2}{|c|}{$\begin{array}{l}\text { Restricted sample: } \\
\text { religion controls }\end{array}$} \\
\hline & (1) & (2) & (3) & (4) & (5) & (6) \\
\hline \multicolumn{7}{|c|}{ A: Physical Violence } \\
\hline \multirow[t]{2}{*}{$\operatorname{Ln}\left(U^{f}\right)$} & 0.171 & $0.347^{*}$ & $-0.534 * * *$ & $-0.519 * * *$ & $-0.502^{* * *}$ & $-0.506^{* * *}$ \\
\hline & $(0.148)$ & $(0.178)$ & $(0.081)$ & $(0.083)$ & $(0.107)$ & $(0.108)$ \\
\hline \multirow[t]{2}{*}{$\operatorname{Ln}\left(\mathrm{U}^{\mathrm{m}}\right)$} & $-0.312^{* *}$ & $-0.479 * *$ & $0.508^{* * *}$ & $0.497 * * *$ & $0.458^{* * *}$ & $0.462 * * *$ \\
\hline & $(0.151)$ & $(0.182)$ & $(0.086)$ & $(0.088)$ & $(0.163)$ & $(0.164)$ \\
\hline Observations & 381730 & 381730 & 381730 & 348165 & 206641 & 206641 \\
\hline P-value F-test & 0.107 & 0.026 & 0.000 & 0.000 & 0.002 & 0.002 \\
\hline Mean Violence & 0.182 & 0.182 & 0.182 & 0.181 & 0.187 & 0.187 \\
\hline Mean $\operatorname{Ln}\left(\mathrm{U}^{\mathrm{f}}\right)$ & 0.018 & 0.018 & 0.018 & 0.024 & 0.062 & 0.062 \\
\hline Mean $\mathrm{Ln}\left(\mathrm{U}^{\mathrm{m}}\right)$ & 0.008 & 0.008 & 0.008 & 0.012 & 0.019 & 0.019 \\
\hline \multicolumn{7}{|c|}{ B: Sexual Violence } \\
\hline \multirow{2}{*}{$\operatorname{Ln}\left(\mathrm{U}^{\mathrm{f}}\right)$} & 0.038 & 0.089 & -0.172 & -0.172 & -0.159 & -0.160 \\
\hline & $(0.126)$ & $(0.142)$ & $(0.107)$ & $(0.109)$ & $(0.116)$ & $(0.115)$ \\
\hline \multirow[t]{2}{*}{$\operatorname{Ln}\left(\mathrm{U}^{\mathrm{m}}\right)$} & -0.150 & -0.186 & 0.141 & 0.140 & 0.105 & 0.107 \\
\hline & $(0.112)$ & $(0.135)$ & $(0.107)$ & $(0.107)$ & $(0.159)$ & $(0.159)$ \\
\hline Observations & 275718 & 275718 & 275718 & 268173 & 199929 & 199929 \\
\hline P-value F-test & 0.436 & 0.325 & 0.150 & 0.154 & 0.336 & 0.332 \\
\hline Mean Violence & 0.068 & 0.068 & 0.068 & 0.067 & 0.075 & 0.075 \\
\hline Mean $\operatorname{Ln}\left(\mathrm{U}^{\mathrm{f}}\right)$ & 0.021 & 0.021 & 0.021 & 0.023 & 0.061 & 0.061 \\
\hline Mean $\operatorname{Ln}\left(\mathrm{U}^{\mathrm{m}}\right)$ & 0.002 & 0.002 & 0.002 & 0.003 & 0.016 & 0.016 \\
\hline \multicolumn{7}{|l|}{ C: Any Violence } \\
\hline \multirow[t]{2}{*}{$\operatorname{Ln}\left(U^{f}\right)$} & 0.204 & 0.326 & $-0.584 * * *$ & $-0.581 * * *$ & $-0.509 * * *$ & $-0.512^{* * *}$ \\
\hline & $(0.176)$ & $(0.215)$ & $(0.148)$ & $(0.153)$ & $(0.150)$ & $(0.150)$ \\
\hline \multirow[t]{2}{*}{$\mathrm{Ln}\left(\mathrm{U}^{\mathrm{m}}\right)$} & $-0.401 * *$ & $-0.521 * *$ & $0.535^{* * *}$ & $0.527 * * *$ & $0.426^{*}$ & $0.430^{*}$ \\
\hline & $(0.178)$ & $(0.219)$ & $(0.157)$ & $(0.159)$ & $(0.216)$ & $(0.217)$ \\
\hline Observations & 274002 & 274002 & 274002 & 266517 & 198400 & 198400 \\
\hline P-value F-test & 0.094 & 0.058 & 0.001 & 0.001 & 0.017 & 0.017 \\
\hline Mean Violence & 0.198 & 0.198 & 0.198 & 0.198 & 0.208 & 0.208 \\
\hline Mean $\operatorname{Ln}\left(\mathrm{U}^{\mathrm{f}}\right)$ & 0.021 & 0.021 & 0.021 & 0.022 & 0.061 & 0.061 \\
\hline Mean $\operatorname{Ln}\left(\mathrm{U}^{\mathrm{m}}\right)$ & 0.002 & 0.002 & 0.002 & 0.003 & 0.017 & 0.017 \\
\hline Year FE & & $\mathrm{Y}$ & $\mathrm{Y}$ & $\mathrm{Y}$ & $\mathrm{Y}$ & $\mathrm{Y}$ \\
\hline Country FE & & & Y & $\mathrm{Y}$ & $\mathrm{Y}$ & Y \\
\hline $\mathrm{X}$ controls & & & & Y & $\mathrm{Y}$ & Y \\
\hline Religion controls & & & & & & $\mathrm{Y}$ \\
\hline
\end{tabular}

Source:

Authors' analysis based on data from the Demographic and Health Surveys (DHS).

Notes:

${ }^{*} \mathrm{p}<0.10,{ }^{* *} \mathrm{p}<0.05,{ }^{* * *} \mathrm{p}<0.01$. Standard errors are robust to arbitrary forms of heteroscedasticity and are clustered at the country level. All estimates are of equation (1). The dependent variable in each regression is a binary dummy variable taking the value one if the individual female respondent was a victim of violence, defined as physical (panel A), sexual (panel B) or either (panel C) in the last twelve months. P-value F-test refers to the F-test that the coefficients on $\ln \left(\mathrm{U}^{\mathrm{f}}\right)$ and $\ln \left(\mathrm{U}^{\mathrm{m}}\right)$ are equal. $\mathrm{X}$ is a vector of controls for age and education of respondent, education of her spouse, and urban location. The restricted sample is the sub-sample of surveys for which information on respondent religion is non-missing. 
Table 2: Heterogeneity by access to divorce

\begin{tabular}{llll}
\hline & $(\mathrm{I})$ & $(\mathrm{II})$ & $(\mathrm{III})$ \\
& Physical & Sexual & Any \\
& Violence & Violence & Violence \\
\hline A: Equal access to divorce & & \\
\hline $\ln \left(\mathrm{U}_{\mathrm{f}}\right)$ & $1.433^{* * *}$ & $1.526^{* * *}$ & $1.211^{* * *}$ \\
& $(0.087)$ & $(0.019)$ & $(0.051)$ \\
$\ln \left(\mathrm{U}_{\mathrm{m}}\right)$ & $-0.789^{* * *}$ & $-0.815^{* * *}$ & $-0.662^{* * *}$ \\
& $(0.045)$ & $(0.009)$ & $(0.023)$ \\
Observations & 95040 & 35794 & 35736 \\
$\mathrm{X}$ controls & $\mathrm{Y}$ & $\mathrm{Y}$ & $\mathrm{Y}$ \\
Country and Year FE & $\mathrm{Y}$ & $\mathrm{Y}$ & $\mathrm{Y}$ \\
\hline B: Women lack equal access to divorce & & \\
\hline Ln $\left(\mathrm{U}_{\mathrm{f}}\right)$ & $-0.517^{* * *}$ & $-0.290^{* *}$ & $-0.631^{* *}$ \\
& $(0.107)$ & $(0.131)$ & $(0.243)$ \\
Ln $\left(\mathrm{U}_{\mathrm{m}}\right)$ & $0.562^{* * *}$ & 0.200 & $0.597 * * *$ \\
& $(0.077)$ & $(0.121)$ & $(0.191)$ \\
Observations & 253125 & 232379 & 230781 \\
X controls & $\mathrm{Y}$ & $\mathrm{Y}$ & $\mathrm{Y}$ \\
Country and Year FE & $\mathrm{Y}$ & $\mathrm{Y}$ & $\mathrm{Y}$ \\
\hline
\end{tabular}

Source:

Authors' analysis based on data from the Demographic and Health Surveys (DHS).

Notes:

$* \mathrm{p}<0.10, * * \mathrm{p}<0.05, * * * \mathrm{p}<0.01$. Standard errors are robust to arbitrary forms of heteroscedasticity and are clustered at the country level. All estimates are of equation (1). The dependent variable in each regression is a binary dummy variable taking the value one if the individual female respondent was a victim of violence, defined as physical (I), sexual (II) or either (III) in the last twelve months. $\mathrm{X}$ is a vector of controls for age and education of respondent, education of her spouse, and urban location. Details on the countries in samples in panel A and B, as well as the definition of equality in access to divorce, is given in Table S1.2. Differences in observations between columns (I) compared to (II) and (III) are due to information on sexual violence not being collected in all surveys (see Table S1.1). 
Table 3: Robustness of results to inclusion of country-specific trends

\begin{tabular}{llll}
\hline & $(1)$ & $(2)$ & $(3)$ \\
& Physical & Sexual & Any Violence \\
& Violence & Violence & \\
\hline $\ln \left(\mathrm{U}^{f}\right)$ & $-0.301^{* * *}$ & 0.050 & $-0.249^{* * *}$ \\
& $(0.071)$ & $(0.060)$ & $(0.063)$ \\
$\ln \left(\mathrm{U}^{\mathrm{m}}\right)$ & $0.308^{* *}$ & -0.070 & $0.254^{* * *}$ \\
& $(0.135)$ & $(0.054)$ & $(0.085)$ \\
Observations & 348165 & 268173 & 266517 \\
& & & \\
P-value F-test & 0.006 & 0.287 & 0.001 \\
Mean Violence & 0.181 & 0.067 & 0.198 \\
X controls & $\mathrm{Y}$ & $\mathrm{Y}$ & $\mathrm{Y}$ \\
Year FE & $\mathrm{Y}$ & $\mathrm{Y}$ & $\mathrm{Y}$ \\
Country FE & $\mathrm{Y}$ & $\mathrm{Y}$ & $\mathrm{Y}$ \\
Country Specific Trends & $\mathrm{Y}$ & $\mathrm{Y}$ & $\mathrm{Y}$ \\
\hline
\end{tabular}

Source:

Authors' analysis based on data from the Demographic and Health Surveys (DHS).

Notes:

* $\mathrm{p}<0.10$, ** $\mathrm{p}<0.05$, *** $\mathrm{p}<0.01$. Standard errors are robust to arbitrary forms of heteroscedasticity and are clustered at the country level. The dependent variable in each regression is a binary dummy variable taking the value one if the individual female respondent was a victim of violence, defined as physical (I), sexual (II) or either (III) in the last twelve months. X is a vector of controls for age and education of respondent, education of her spouse, and urban location. In addition, country-specific trends are controlled for. 
Table 4: Use of first difference in the logarithm of the unemployment rate

\begin{tabular}{|c|c|c|c|}
\hline & $\begin{array}{c}\text { (1) } \\
\text { Physical } \\
\text { Violence }\end{array}$ & $\begin{array}{c}(2) \\
\text { Sexual } \\
\text { Violence }\end{array}$ & $\begin{array}{c}(3) \\
\text { Any } \\
\text { Violence }\end{array}$ \\
\hline$\Delta \ln \left(\mathrm{U}_{\mathrm{f}}\right)$ & $\begin{array}{l}-0.150^{* *} \\
(0.069)\end{array}$ & $\begin{array}{l}-0.020 \\
(0.080)\end{array}$ & $\begin{array}{l}-0.195 \\
(0.132)\end{array}$ \\
\hline$\Delta \ln \left(\mathrm{U}_{\mathrm{m}}\right)$ & $\begin{array}{l}0.177 * * \\
(0.071)\end{array}$ & $\begin{array}{l}0.024 \\
(0.073)\end{array}$ & $\begin{array}{l}0.197 \\
(0.118)\end{array}$ \\
\hline Observations & 348165 & 268173 & 266517 \\
\hline Mean Violence & 0.181 & 0.067 & 0.198 \\
\hline $\mathrm{X}$ controls & Y & Y & Y \\
\hline Year FE & $\mathrm{Y}$ & Y & Y \\
\hline Country FE & Y & Y & Y \\
\hline
\end{tabular}

Source:

Authors' analysis based on data from the Demographic and Health Surveys (DHS).

Notes:

$* \mathrm{p}<0.10$, ** $\mathrm{p}<0.05, * * * \mathrm{p}<0.01$. Standard errors are robust to arbitrary forms of heteroscedasticity and are clustered at the country level. All estimates are of equation (2). The dependent variable in each regression is a binary dummy variable taking the value one if the individual female respondent was a victim of violence, defined as physical (1), sexual (2) or either (3) in the last twelve months. $\mathrm{X}$ is a vector of controls for age and education of respondent, education of her spouse, and urban location. Relative to Table 1, the HP-filter detrended unemployment rates are replaced with the first difference in the logarithm of the unemployment rates. 
Table 5: Alternative Specification including total unemployment and the ratio of male to female unemployment

\begin{tabular}{llll}
\hline & \multicolumn{1}{c}{$(1)$} & $(2)$ & $(3)$ \\
& $\begin{array}{c}\text { Physical } \\
\text { Violence }\end{array}$ & $\begin{array}{c}\text { Sexual } \\
\text { Violence }\end{array}$ & $\begin{array}{c}\text { Any } \\
\text { Violence }\end{array}$ \\
\hline $\ln (\mathrm{U})$ & -0.019 & -0.030 & -0.049 \\
& $(0.055)$ & $(0.037)$ & $(0.066)$ \\
$\ln \left(\mathrm{U}^{\text {ratio }}\right)$ & $0.509^{* * *}$ & 0.157 & $0.554^{* * *}$ \\
& $(0.082)$ & $(0.108)$ & $(0.155)$ \\
Observations & 348165 & 268173 & 266517 \\
& & & \\
X controls & $\mathrm{Y}$ & $\mathrm{Y}$ & $\mathrm{Y}$ \\
Year FE & $\mathrm{Y}$ & $\mathrm{Y}$ & $\mathrm{Y}$ \\
Country FE & $\mathrm{Y}$ & $\mathrm{Y}$ & $\mathrm{Y}$ \\
\hline
\end{tabular}

Source:

Authors' analysis based on data from the Demographic and Health Surveys (DHS).

Notes:

$* \mathrm{p}<0.10, * * \mathrm{p}<0.05, * * * \mathrm{p}<0.01$. Standard errors are robust to arbitrary forms of heteroscedasticity and are clustered at the country level. All estimates are of equation (3). The dependent variable in each regression is a binary dummy variable taking the value one if the individual female respondent was a victim of violence, defined as physical (1), sexual (2) or either (3) in the last twelve months. $\mathrm{X}$ is a vector of controls for age and education of respondent, education of her spouse, and urban location. Relative to Table 1, the HP-filter detrended male and female unemployment rates are replaced with the HP-filter detrended unemployment, $\ln (\mathrm{U})$, and the detrended ratio of the male to female unemployment, $\ln \left(\mathrm{U}^{\text {ratio }}\right)$. 


\section{Supplementary Online Appendix}

Intimate Partner Violence: The influence of job opportunities for men and women Sonia Bhalotra, Uma Kambhampati, Samantha Rawlings, Zahra Siddique 


\section{Supplementary Online Appendix S1: Additional Figures and Tables}

Figure S1.1: Variation in unemployment rate measures over time, within sample

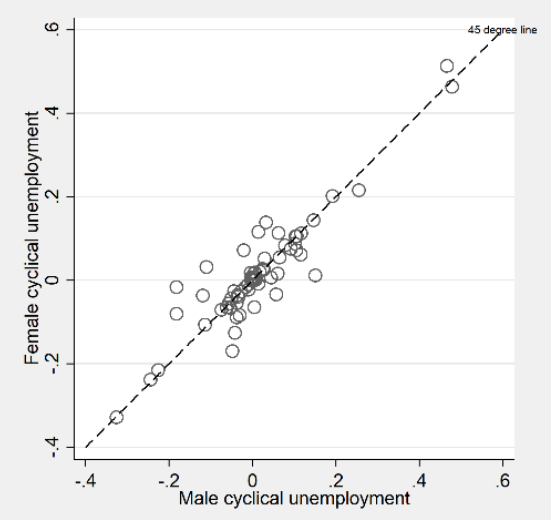

(a) Plot of cyclical log male unemployment $\left(\ln U^{\mathrm{m}}\right)$ against cyclical $\log$ female unemployment $\left(\ln U^{f}\right)$

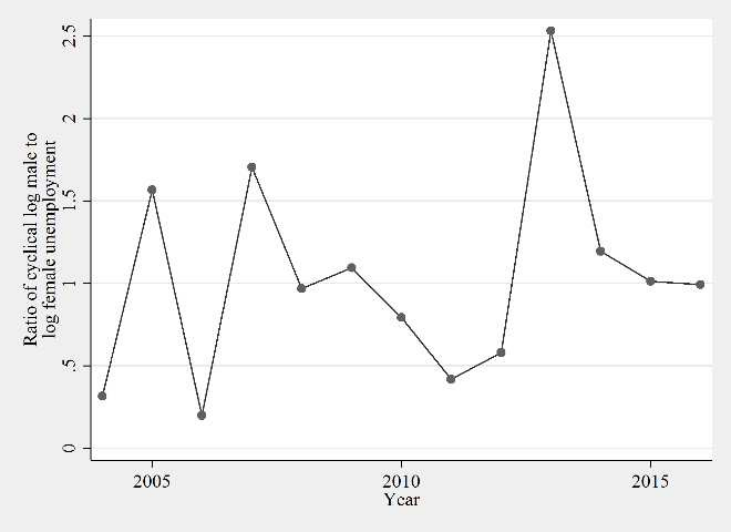

(c) Ratio of cyclical log male to log female unemployment $\left(\frac{\ln U^{m}}{\ln U^{f}}\right)$ over time

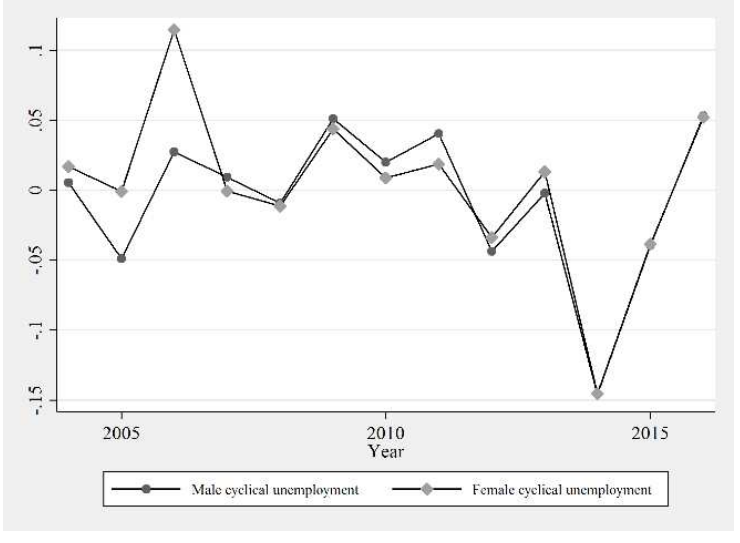

(b) Cyclical $\log$ male $\left(\ln U^{m}\right)$ and female unemployment $\left(\ln U^{f}\right)$ over time

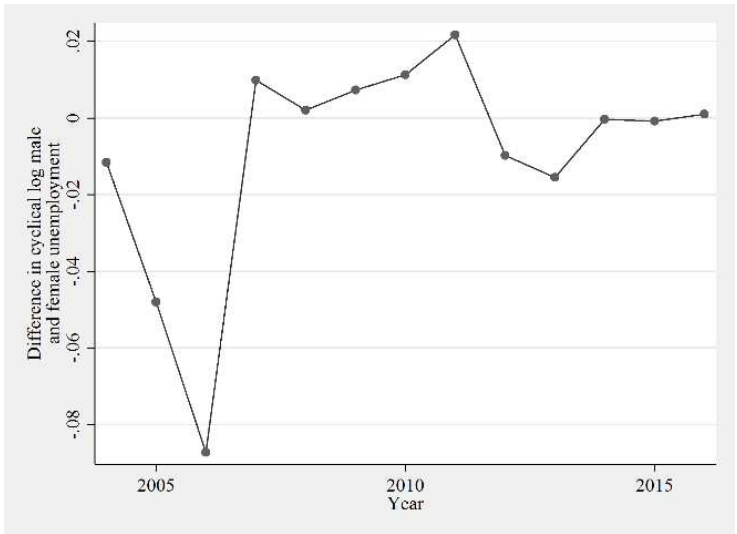

(d) Difference in cyclical log male and female unemployment $\left(\ln U^{m}-\ln U^{f}\right)$ over time

\section{Source:}

Authors' analysis based on data from the Demographic and Health Surveys (DHS).

Notes:

1. Figure (a) shows a plot of the cyclical log female unemployment against cyclical log male unemployment, for the sample used in Table 1 . A $45^{\circ}$ line is overlaid on the graph.

2. Figure (b) shows plots of both cyclical log female unemployment and cyclical log male unemployment over time, for the sample used in Table 1.

3. Figure (c) shows a plot of the ratio of cyclical log male to female unemployment over time, for the sample used in Table 1.

4. Figure (d) shows a plot of the difference in cyclical log male and female unemployment over time, for the sample used in Table 1. 
Figure S1.2: Rates of male and female unemployment against physical violence

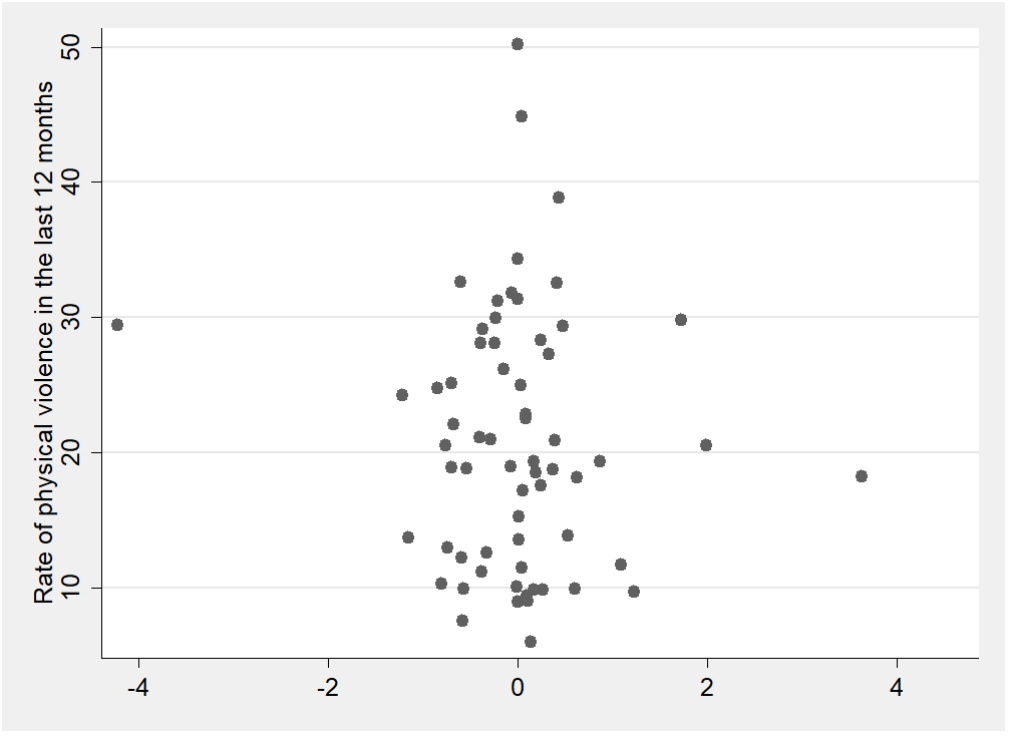

(a) Country-year cyclical female unemployment against physical violence rate.

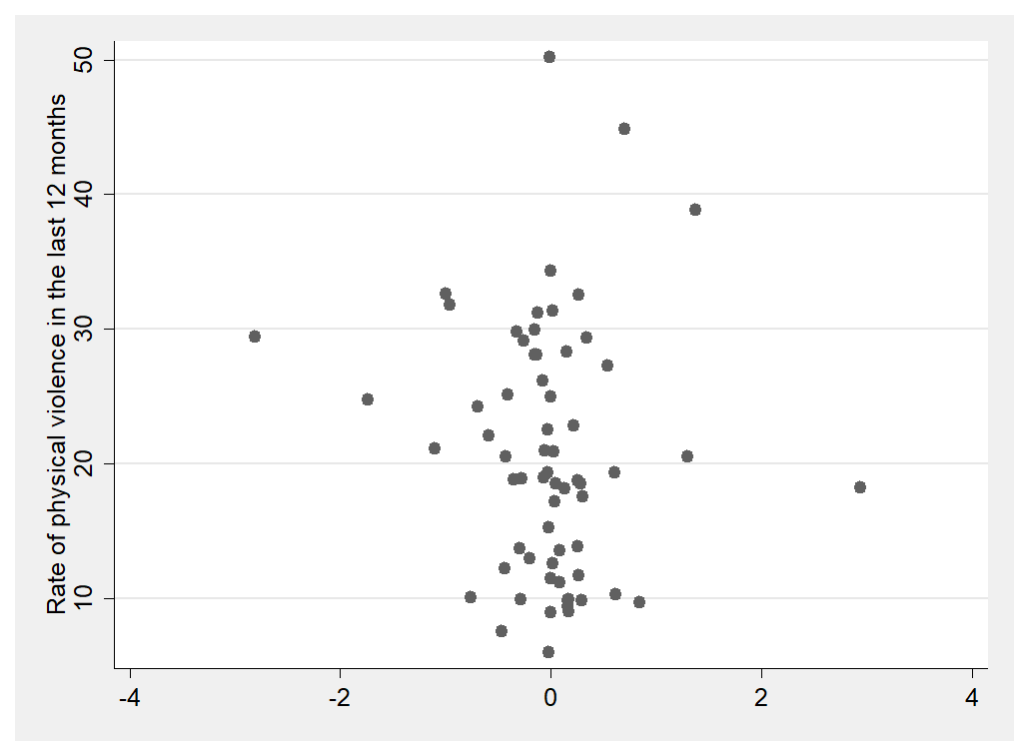

(b) Country-year cyclical male unemployment against physical violence rate.

Source:

Authors' analysis based on data from the Demographic and Health Surveys (DHS).

Notes:

1. Physical violence rate is the country-year percentage of women who experienced physical violence at the hands of their partner in the last 12 months. 
Figure S1.3: Variation in estimated coefficients across sample physical and/or sexual violence

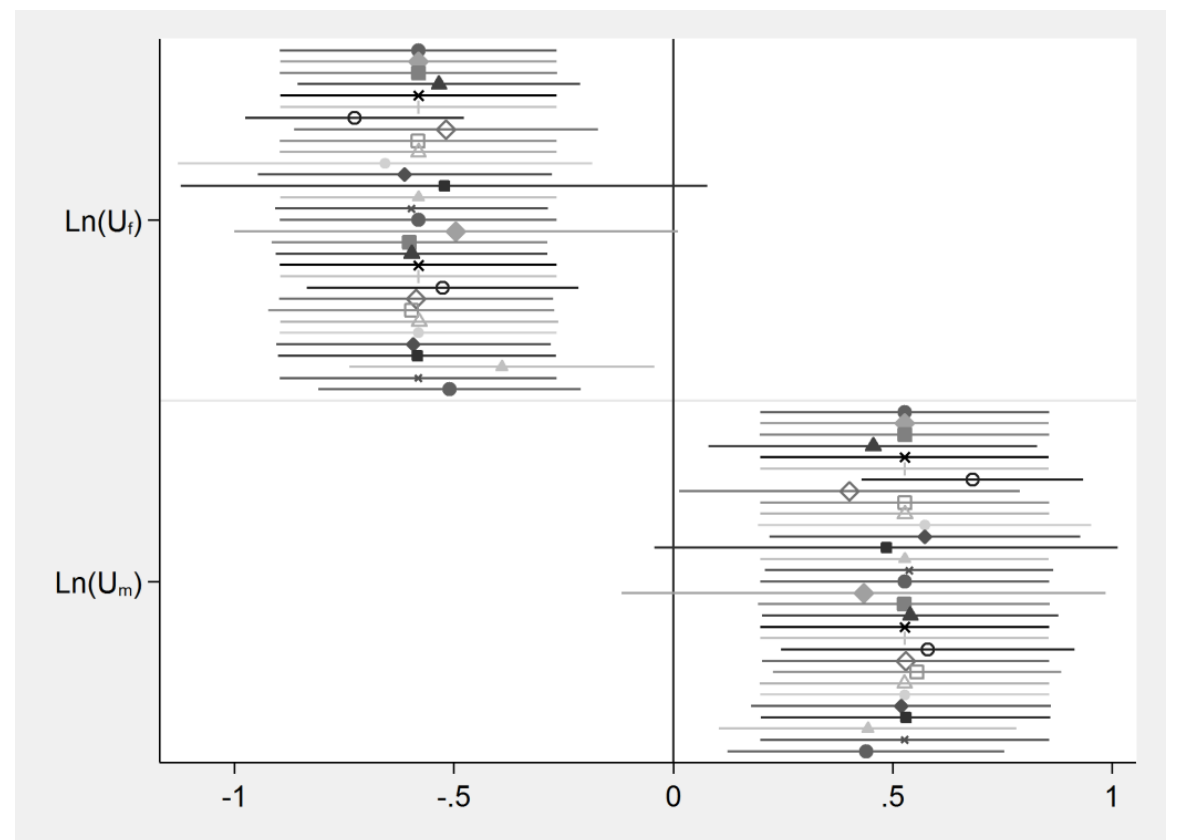

Source:

Authors' analysis based on data from the Demographic and Health Surveys (DHS).

Notes:

As in figures $2 \mathrm{a}$ and $2 \mathrm{~b}$ this figure shows estimated coefficients from a leave one out analysis, with $95 \%$ confidence intervals. The dependent variable is an indicator for whether the woman experienced physical and/or sexual violence. Estimations include individual level controls, and country and year fixed effects. 
Table S1.1: Countries and years in sample

\begin{tabular}{|c|c|}
\hline Physical Violence Sample & Sexual Abuse Sample \\
\hline Azerbaijan; 2006 & Azerbaijan; 2006 \\
\hline Bangladesh, 2007 & Burkina Faso; 2010 \\
\hline Burkina Faso; 2010 & Cambodia; 2005, 2006, 2014 \\
\hline Cambodia; 2005, 2006, 2014 & Democratic Republic of Congo; 2007, 2013, 2014 \\
\hline Cameroon, 2011 & Dominican Republic; 2007 , 2013 \\
\hline Colombia 2004, 2005, 2009, 2010 & Gabon; 2012 \\
\hline Democratic Republic of Congo; 2007, 2013, 2014 & Ghana; 2008 \\
\hline Dominican Republic; 2007 , 2013 & Haiti; 2005, 2006, 2012 \\
\hline Gabon; 2012 & Honduras; 2011, 2012 \\
\hline Ghana; 2008 & India; 2005, 2006 \\
\hline Haiti; 2005, 2006, 2012 & Kenya; 2008, 2009, 2014 \\
\hline Honduras; 2011, 2012 & Kyrgyz Republic; 2012 \\
\hline India; 2005, 2006 & Liberia; 2006, 2007 \\
\hline Jordan, 2007, 2012 & Malawi; 2010, 2015, 2016 \\
\hline Kenya; 2008, 2009, 2014 & Mali; 2012, 2013 \\
\hline Kyrgyz Republic; 2012 & Mozambique; 2011 \\
\hline Liberia; 2006, 2007 & Peru; 2010, 2011, 2012 \\
\hline Malawi; 2010, 2015, 2016 & Philippines; 2008 , 2013 \\
\hline Mali; 2012, 2013 & Rwanda; 2014, 2015 \\
\hline Mozambique; 2011 & Sao Tome and Principe; 2008, 2009 \\
\hline Pakistan, 2012, 2013 & Tajikistan; 2012 \\
\hline Peru; 2010, 2011, 2012 & Tanzania; 2009, 2010, 2015, 2016 \\
\hline Philippines; 2008 , 2013 & Timor Leste; 2009, 2010 \\
\hline Rwanda; 2014, 2015 & Uganda; 2006, 2011 \\
\hline Sao Tome and Principe; 2008, 2009 & Ukraine; 2007 \\
\hline Tajikistan; 2012 & Zambia; 2007 , 2013, 2014 \\
\hline \multicolumn{2}{|l|}{ Tanzania; 2009, 2010, 2015, 2016} \\
\hline \multicolumn{2}{|l|}{ Timor Leste; 2009, 2010} \\
\hline \multicolumn{2}{|l|}{ Uganda; 2006, 2011} \\
\hline \multicolumn{2}{|l|}{ Ukraine; 2007} \\
\hline Zambia; 2007 , 2013, 2014 & \\
\hline
\end{tabular}

Source: Demographic and Health Surveys (DHS). 
Table S1.2: Equality in divorce access

\begin{tabular}{ll}
\hline Equal access to divorce & Inequality in access to divorce \\
\hline Colombia & Azerbaijan \\
Haiti & Bangladesh \\
Honduras & Burkina Faso \\
Kyrgyz Republic & Cambodia \\
Sozambique & Cameroon \\
Ukraine & Democratic Republic of Congo \\
& Dominican Republic \\
UK ${ }^{*}$ & Gabon \\
US & Ghana \\
& India \\
& Jordan \\
Kenya \\
Liberia \\
Malawi \\
Mali \\
Pakistan \\
Peru \\
Philippines \\
Rwanda \\
Tajikistan \\
Tanzania \\
Timor Leste \\
Uganda \\
Zambia \\
\hline
\end{tabular}

Source:

OECD 2019 Social and Institutions Gender Index, https://www.genderindex.org/

Notes:

1. Equality in access to divorce is defined in the SIGI as "Women have both the same rights to initiate divorce and the same requirements to finalise divorce or annulment as men, without negative repercussions on their parental authority. This applies to all groups of women.

Customary, religious and traditional laws or practices do not discriminate against women's rights regarding divorce or parental authority after divorce".

2. ${ }^{*}$ Not in sample; included for comparative purposes. 
Table S1.3: Impact of cyclical fluctuations in total (male plus female) unemployment rates on IPV

\begin{tabular}{|c|c|c|c|c|}
\hline & (1) & (2) & (3) & (4) \\
\hline \multicolumn{5}{|c|}{ A: Physical Violence } \\
\hline \multirow[t]{2}{*}{$\ln (\mathrm{U})$} & -0.104 & -0.107 & 0.061 & 0.063 \\
\hline & $(0.089)$ & (0.093) & (0.104) & $(0.109)$ \\
\hline Observations & 381730 & 381730 & 381730 & 348165 \\
\hline \multicolumn{5}{|c|}{ B: Sexual Violence } \\
\hline \multirow[t]{2}{*}{$\ln (\mathrm{U})$} & $-0.093 *$ & $-0.089 *$ & 0.003 & 0.002 \\
\hline & (0.051) & $(0.048)$ & $(0.049)$ & $(0.050)$ \\
\hline Observations & 275718 & 275718 & 275718 & 268173 \\
\hline \multicolumn{5}{|c|}{ C: Any Violence } \\
\hline \multirow[t]{2}{*}{$\ln (\mathrm{U})$} & -0.146 & $-0.177 *$ & 0.066 & 0.061 \\
\hline & $(0.100)$ & $(0.087)$ & $(0.121)$ & $(0.123)$ \\
\hline Observations & 274002 & 274002 & 274002 & 266517 \\
\hline \multicolumn{2}{|l|}{ Year FE } & Y & $\mathrm{Y}$ & $\mathrm{Y}$ \\
\hline \multirow{2}{*}{\multicolumn{2}{|c|}{$\begin{array}{l}\text { Country FE } \\
\text { X controls }\end{array}$}} & & Y & Y \\
\hline & & & & Y \\
\hline \multicolumn{5}{|c|}{$\begin{array}{l}\text { Source: } \\
\text { Authors' analysis based on data from the Demographic and Health } \\
\text { Surveys (DHS). }\end{array}$} \\
\hline \multicolumn{5}{|c|}{$\begin{array}{l}\text { Notes: } \\
* \mathrm{p}<0.10,{ }^{*} \mathrm{p}<0.05,{ }^{* *} \mathrm{p}<0.01 \text {. The dependent variables, controls } \\
\text { and standard error adjustments are as in Table } 1 \text {. Relative to Table } \\
1 \text {, the study now uses the total (male }+ \text { female) unemployment rate } \\
\text { rather than include the male and female rates separately. }\end{array}$} \\
\hline
\end{tabular}


Table S1.4: Impact of cyclical fluctuations in male and female unemployment rates on IPV; restricted sample of countries for which two or more years of data are available

\begin{tabular}{|c|c|c|c|c|}
\hline & $(1)$ & $(2)$ & (3) & (4) \\
\hline \multicolumn{5}{|c|}{ A: Physical Violence } \\
\hline \multirow[t]{2}{*}{$\ln \left(\mathrm{U}^{\mathrm{f}}\right)$} & 0.177 & 0.237 & $-0.534 * * *$ & $-0.519 * * *$ \\
\hline & $(0.162)$ & $(0.210)$ & $(0.082)$ & $(0.083)$ \\
\hline \multirow[t]{2}{*}{$\ln \left(\mathrm{U}^{\mathrm{m}}\right)$} & $-0.355^{* *}$ & $-0.432 * *$ & $0.508^{* * *}$ & $0.496^{* * *}$ \\
\hline & $(0.158)$ & $(0.200)$ & $(0.086)$ & $(0.089)$ \\
\hline Observations & 344239 & 344239 & 344239 & 311775 \\
\hline P-value F-test & 0.102 & 0.110 & 0.000 & 0.000 \\
\hline Mean Violence & 0.184 & 0.184 & 0.184 & 0.183 \\
\hline Mean $\ln \left(\mathrm{U}^{f}\right)$ & 0.017 & 0.017 & 0.017 & 0.023 \\
\hline Mean $\ln \left(\mathrm{U}^{\mathrm{m}}\right)$ & 0.008 & 0.008 & 0.008 & 0.012 \\
\hline \multicolumn{5}{|c|}{ B: Sexual Violence } \\
\hline \multirow[t]{2}{*}{$\ln \left(\mathrm{U}^{f}\right)$} & 0.036 & 0.105 & -0.172 & -0.172 \\
\hline & $(0.159)$ & $(0.191)$ & $(0.108)$ & $(0.110)$ \\
\hline \multirow[t]{2}{*}{$\ln \left(\mathrm{U}^{\mathrm{m}}\right)$} & -0.172 & -0.222 & 0.141 & 0.140 \\
\hline & $(0.138)$ & $(0.182)$ & $(0.108)$ & $(0.108)$ \\
\hline Observations & 238067 & 238067 & 238067 & 231632 \\
\hline P-value F-test & 0.490 & 0.388 & 0.160 & 0.165 \\
\hline Mean Violence & 0.073 & 0.073 & 0.073 & 0.072 \\
\hline Mean $\ln \left(\mathrm{U}^{f}\right)$ & 0.019 & 0.019 & 0.019 & 0.021 \\
\hline Mean $\ln \left(\mathrm{U}^{\mathrm{m}}\right)$ & 0.001 & 0.001 & 0.001 & 0.003 \\
\hline \multicolumn{5}{|l|}{ C: Any Violence } \\
\hline \multirow[t]{2}{*}{$\ln \left(\mathrm{U}^{\mathrm{f}}\right)$} & 0.208 & 0.211 & $-0.584 * * *$ & $-0.581 * * *$ \\
\hline & $(0.203)$ & $(0.237)$ & $(0.150)$ & $(0.154)$ \\
\hline \multirow[t]{2}{*}{$\ln \left(\mathrm{U}^{\mathrm{m}}\right)$} & $-0.458^{* *}$ & $-0.475^{*}$ & $0.535^{* * *}$ & $0.526^{* * *}$ \\
\hline & $(0.195)$ & $(0.248)$ & $(0.158)$ & $(0.161)$ \\
\hline Observations & 236542 & 236542 & 236542 & 230155 \\
\hline P-value F-test & 0.107 & 0.171 & 0.002 & 0.002 \\
\hline Mean Violence & 0.203 & 0.203 & 0.203 & 0.203 \\
\hline Mean $\ln \left(\mathrm{U}^{f}\right)$ & 0.019 & 0.019 & 0.019 & 0.021 \\
\hline Mean $\ln \left(\mathrm{U}^{\mathrm{m}}\right)$ & 0.001 & 0.001 & 0.001 & 0.003 \\
\hline Year FE & & $\mathrm{Y}$ & $\mathrm{Y}$ & $\mathrm{Y}$ \\
\hline Country FE & & & $\mathrm{Y}$ & $\mathrm{Y}$ \\
\hline $\mathrm{X}$ controls & & & & $\mathrm{Y}$ \\
\hline
\end{tabular}

Source:

Authors' analysis based on data from the Demographic and Health Surveys (DHS).

Notes:

${ }^{*} \mathrm{p}<0.10,{ }^{* *} \mathrm{p}<0.05,{ }^{* * *} \mathrm{p}<0.01$. The dependent variables, controls and standard error adjustments are as in Table 1. Relative to Table 1, the sample is now restricted to only those countries for which two or more years of data on women are available. 
Table S1.5: Alternative dependent variables - using indices of IPV

\begin{tabular}{lllll}
\hline & $(1)$ & $(2)$ & $(3)$ & $(4)$ \\
\hline A: Physical Violence & & & & \\
$\ln \left(\mathrm{U}^{f}\right)$ & -0.007 & $-0.373^{* * *}$ & $-0.409^{* * *}$ & $-0.386^{* * *}$ \\
& $(0.029)$ & $(0.120)$ & $(0.109)$ & $(0.119)$ \\
$\ln \left(\mathrm{U}^{\mathrm{m}}\right)$ & -0.008 & $0.347^{* * *}$ & $0.331^{* * *}$ & $0.325^{* *}$ \\
& $(0.042)$ & $(0.108)$ & $(0.115)$ & $(0.125)$ \\
Observations & 381730 & 381730 & 381730 & 348165 \\
Mean Violence Index & 0.018 & 0.018 & 0.018 & 0.018 \\
\hline B: Sexual Violence & & & & \\
$\ln \left(\mathrm{U}^{f}\right)$ & $-0.164^{* *}$ & $-0.953^{* * *}$ & $-0.881^{* * *}$ & $-0.887 * * *$ \\
& $(0.074)$ & $(0.185)$ & $(0.270)$ & $(0.278)$ \\
$\ln \left(\mathrm{U}^{\mathrm{m}}\right)$ & $0.173^{* *}$ & $0.847^{* * *}$ & $0.828^{* * *}$ & $0.834^{* * *}$ \\
& $(0.084)$ & $(0.158)$ & $(0.242)$ & $(0.244)$ \\
Observations & 275718 & 275718 & 275718 & 268173 \\
Mean Violence Index & -0.001 & -0.001 & -0.001 & -0.001 \\
\hline C: Any Violence & & & & \\
$\ln \left(\mathrm{U}^{f}\right)$ & -0.088 & $-0.725^{* * *}$ & $-0.668^{* * *}$ & $-0.679 * * *$ \\
& $(0.052)$ & $(0.121)$ & $(0.205)$ & $(0.213)$ \\
$\ln \left(\mathrm{U}^{\mathrm{m}}\right)$ & 0.084 & $0.642^{* * *}$ & $0.601 * * *$ & $0.610^{* * *}$ \\
& $(0.066)$ & $(0.111)$ & $(0.206)$ & $(0.212)$ \\
Observations & 274002 & 274002 & 274002 & 266517 \\
Mean Violence Index & 0.008 & 0.008 & 0.008 & 0.008 \\
\hline Year FE & & $\mathrm{Y}$ & $\mathrm{Y}$ & $\mathrm{Y}$ \\
Country FE & & & $\mathrm{Y}$ & $\mathrm{Y}$ \\
X controls & & & & $\mathrm{Y}$ \\
\hline
\end{tabular}

Source:

Authors' analysis based on data from the Demographic and Health Surveys (DHS).

Notes:

${ }^{*} \mathrm{p}<0.10,{ }^{* *} \mathrm{p}<0.05, * * * \mathrm{p}<0.01$. Standard errors are robust to arbitrary forms of heteroscedasticity and are clustered at the country level. $\mathrm{X}$ is a vector of controls for age and education of respondent, education of her spouse, and urban location. Relative to Table 1, the dependent variables are now indices rather than binary constructs. 
Table S1.6: Replacing country unemployment rate shocks with individual unemployment status

\begin{tabular}{lllll}
\hline & \multicolumn{1}{c}{$(1)$} & \multicolumn{1}{c}{$(2)$} & \multicolumn{1}{c}{$(3)$} & \multicolumn{1}{c}{$(4)$} \\
\hline A: Physical Violence & & & & \\
Own unemployment & $-0.026^{*}$ & $-0.032^{* *}$ & $-0.036^{* * *}$ & $-0.042^{* * *}$ \\
& $(0.014)$ & $(0.013)$ & $(0.011)$ & $(0.007)$ \\
Spousal unemployment & -0.002 & -0.011 & -0.005 & 0.004 \\
& $(0.023)$ & $(0.018)$ & $(0.017)$ & $(0.018)$ \\
Observations & 88080 & 88080 & 88080 & 74704 \\
\hline B: Sexual Violence & & & & \\
Own unemployment & $-0.033^{* * *}$ & $-0.025^{* * *}$ & $-0.026^{* * *}$ & $-0.026^{* *}$ \\
& $(0.009)$ & $(0.006)$ & $(0.008)$ & $(0.009)$ \\
Spousal unemployment & $0.024^{* *}$ & $0.018^{*}$ & 0.011 & $0.012^{*}$ \\
& $(0.010)$ & $(0.010)$ & $(0.006)$ & $(0.007)$ \\
Observations & 75611 & 75611 & 75611 & 74920 \\
\hline C: Any Violence & & & & \\
Own unemployment & $-0.042^{* *}$ & $-0.042^{* * *}$ & $-0.048^{* * *}$ & $-0.050^{* * *}$ \\
& $(0.015)$ & $(0.012)$ & $(0.009)$ & $(0.007)$ \\
Spousal unemployment & 0.016 & 0.005 & 0.008 & 0.012 \\
& $(0.027)$ & $(0.022)$ & $(0.020)$ & $(0.018)$ \\
Observations & 75356 & 75356 & 75356 & 74669 \\
\hline Year FE & & $\mathrm{Y}$ & $\mathrm{Y}$ & $\mathrm{Y}$ \\
Country FE & & & $\mathrm{Y}$ & $\mathrm{Y}$ \\
X controls & & & & $\mathrm{Y}$ \\
\hline
\end{tabular}

Source:

Authors' analysis based on data from the Demographic and Health Surveys (DHS).

Notes:

$* \mathrm{p}<0.10$, ** $\mathrm{p}<0.05$, *** $\mathrm{p}<0.01$. Standard errors are robust to arbitrary forms of heteroscedasticity and are clustered at the country level. The dependent variable in each regression is a binary dummy variable taking the value one if the individual female respondent was a victim of violence, defined as physical (panel A), sexual (panel B) or either (panel C) in the last twelve months. $\mathrm{X}$ is a vector of controls for age and education of respondent, education of her spouse, and urban location. Relative to Table 1, female and male unemployment rate shocks are replaced with an indicator for the individual unemployment status of the woman and her partner. Information on employment status of partner is available in only 18 of our 32 countries. 